\title{
31. THE SEISMIC STRATIGRAPHY AND SEDIMENTARY HISTORY OF THE EAST MARIANA AND PIGAFETTA BASINS OF THE WESTERN PACIFIC ${ }^{1}$
}

\author{
L. J. Abrams, ${ }^{2}$ R. L. Larson, ${ }^{2}$ T. H. Shipley, ${ }^{3}$ and Y. Lancelot ${ }^{4}$
}

\begin{abstract}
The successful completion of Leg 129, resulting in the first and only holes to penetrate igneous basement (not necessarily layer 2) in the East Mariana and Pigafetta basins, now allows the calibration of our regional multichannel seismic site surveys and the extrapolation of drilling results throughout these oldest Pacific basins. Our study indicates that mid-Cretaceous flows/sills overlie Jurassic/Lower Cretaceous sediments and oceanic crust throughout the East Mariana Basin and the southeast Pigafetta Basin. Jurassic-age oceanic crust and overlying Upper Jurassic-Lower Cretaceous sediments unquestionably exist at Site 801 and extend semicontinuously between Sites 801 and 800 . Turbidite sequences of varying thicknesses and ages are ubiquitous features of both basins. Cretaceous turbidite sequences were derived from Magellan and Marcus-Wake seamounts and seamount chains of Aptian age or younger. The seamounts/atolls of the Caroline Ridge more than $300 \mathrm{~km}$ to the south of Site 802 were the source of extensive Miocene-age volcanogenic turbidites which are restricted to the south central East Mariana Basin, while the carbonate caps that developed on Ita Mai Tai Guyot and other edifices of the Magellan chain were the source for the redeposited shallow-water carbonate sequences recovered along the eastern margin of the East Mariana Basin. The Ogasawara Fracture Zone, Magellan Seamounts, and associated flexural moat separate the Pigafetta Basin from the East Mariana Basin and influence the source and distribution of redeposited material. A distinct basinwide reflection that is correlated with the shallowest chert/porcellanite/clay and chert/chalk sequences in the Pigafetta Basin and East Mariana Basin, respectively, is a time-transgressive horizon (Eocene-Campanian) resulting from the passage of the Pacific Plate beneath the equatorial zone of high productivity.
\end{abstract}

\section{INTRODUCTION}

The correlation of Mesozoic magnetic anomaly sequences in the Pacific Ocean by Larson and Chase (1972), Hilde et al. (1976), and Larson (1976) indicate that the world's oldest in-situ ocean crust lies centered in the far western Pacific, and that isochrons become younger in approximately radial fashion. The most recent magnetic anomaly identifications of Tamaki et al. (1987), Handschumacher et al. (1988), Nakanishi et al. (1989), and Nakanishi et al. (in press) indicates that the oldest portion of this plate tectonic pattern is revealed in the East Mariana Basin (EMB) and Pigafetta Basin (PB). Simple extrapolation of spreading rates from post-M25 anomalies indicates that these basins may contain oceanic crust as old as 175 m.y. (Middle-Jurassic) (Figs. 1 and 2; see also back-pocket fig. 1, Brenner and Angell, this volume).

The inference of Jurassic sediments and basement rocks within the M17 isochron, which encompasses an area equal in size to the contiguous United States, is based entirely on these magnetic lineation correlations. No Jurassic material had been recovered from this region until Ocean Drilling Program (ODP) Leg 129 (November 1989-January 1990), despite eight previous scientific drilling expeditions since 1969, and numerous dredging expeditions ranging back to the $1950 \mathrm{~s}$. The oldest material sampled has almost invariably been of middle to Late Cretaceous age, consisting of chert, chalk, rudists, dolerite sills, basaltic flows, or volcanogenic sediments.

Two technological factors in past geological and geophysical research in the western Pacific have hindered our understanding of the seismic stratigraphy of the EMB and PB, and of deep-sea volcanism in particular. The first is that previous low-volume airgun singlechannel seismic (SCS) and sonobuoy experiments were unable to

\footnotetext{
${ }^{1}$ Larson, R. L., Lancelot, Y., et al., 1992. Proc. ODP, Sci. Results, 129: College Station, TX (Ocean Drilling Program).

${ }^{2}$ Graduate School of Oceanography, University of Rhode Island, Narragansett, RI, 02882, U.S.A.

${ }^{3}$ Institute for Geophysics, University of Texas, Austin, TX 78759, U.S.A.

${ }^{4}$ Laboratoire de Geologie du Quaternaire, CNRS-Luminy, Case 907, 13288 Marseille, Cedex 9, France.
}

adequately define stratigraphic relationships in the western Pacific. The second was the inability to penetrate beneath the Cretaceous sequences described above with the Glomar Challenger's drilling system and less than optimum drill siting because of the inadequate seismic data.

Seismic reflection studies of the EMB and PB presented in this paper imaged oceanic crust, mapped the overlying strata, and identified a site where the JOIDES Resolution was able to recover Jurassic to Tertiary sediments during Leg 129 (Abrams et al., 1988; Lancelot, Larson, et al., 1990). The successful completion of Leg 129 resulted in the first and only holes to penetrate the complete sedimentary sequence overlying igneous basement (not necessarily layer 2 ) in the EMB and PB. This paper utilizes the seismic reflection data to investigate the basinwide distribution, variability and sources of the sedimentary sequences sampled during Leg 129 and selected DSDP Legs in the area.

\section{DATA ACQUISITION AND PROCESSING}

In November-December 1987 the research vessel Fred H. Moore expedition 35-12 (FM35-12) collected over $3900 \mathrm{~km}$ of multichannel seismic (MCS) data using a 3200-m-long receiving array consisting of 96 hydrophone groups each $33.33 \mathrm{~m}$ in length (Fig. 3). The seismic data were demultiplexed and recorded on a GUS 4200 Marine System sampling at $4 \mathrm{~ms}$. The Moore's seismic source consisted of various combinations of airguns shot at approximately $13.8 \mathrm{MPa}(2000 \mathrm{psi})$ every $20 \mathrm{~s}$. The maximum airgun volume achieved was 84.15 liters (L) $\left(5135\right.$ in. $\left.^{3}\right)$ but the mean airgun volume during the 17 days of MCS acquisition was $40.65 \mathrm{~L}\left(2481\right.$ in. $\left.^{3}\right)$. Refraction data collected by seven long-range sonobuoys were also digitally recorded during this regional survey (Abrams et al., in press). The MESOPAC II MCS survey conducted with the Le Suroit during August-September 1989 focused on potential drilling targets first identified on FM35-12, as well as investigating the northern PB within the oldest portion of the $\mathrm{M}$-sequence lineation pattern. Only processed near-channel data from MESOPAC II are used in this study. The MESOPAC II expedition also recorded approximately $3900 \mathrm{~km}$ of MCS data using an array of four to six 1.31-L $\left(80\right.$ in. $^{3}$ ) waterguns fired every $13 \mathrm{~s}$ during vertical 


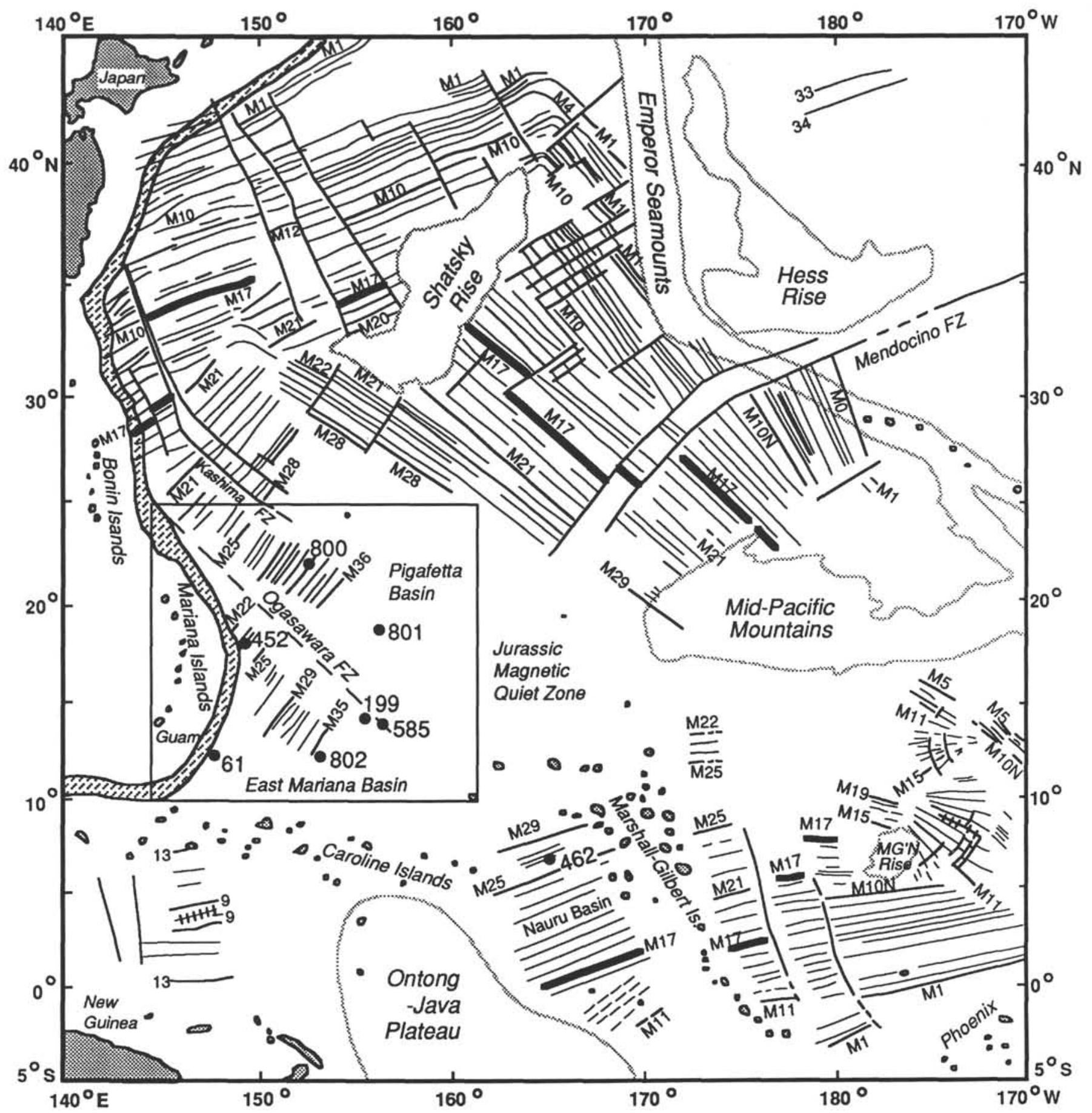

Figure 1. Magnetic lineations of the western Pacific compiled by R. L. Larson from Nakanishi et al. (1989), Mammerickx and Sharman (1988), Larson (1976), Tamaki and Larson (1988), Handschumacher et al. (1988), Sager et al. (1988), and Hilde et al. (1976). Magnetic isochron M17 is highlighted and encloses an area of the northwestern Pacific inferred to contain Jurassic oceanic crust and sediments. Dots locate selected DSDP sites and all three Leg 129 Sites 800, 801, and 802. Area in box is shown in Figures 2, 3, and 7. FZ = fracture zone; MG' $\mathrm{N}=$ Magellan.

incident profiling and two $16.39-\mathrm{L}\left(1000 \mathrm{in}^{3}\right)$ airguns fired every $31 \mathrm{~s}$ while digitally recording refraction data from six long-range sonobuoys. Seismic signals were received by a 2400 -m-long array consisting of 96 hydrophone groups each $25 \mathrm{~m}$ in length. The MESOPAC II expedition also acquired high-quality $3.5-\mathrm{kHz}$ records which were used as a final constraint for Leg 129 site locations.

During both cruises the ships maintained a speed of approximately 5 to 6 knots and navigated primarily by Transit satellite but also by NAVSTAR global positioning system (GPS) with coverage of approximately $5 \mathrm{hr}$ a day. Shot spacing was calculated for the FM35-12 data using final navigation along individual lines, and for MESOPAC II SCS watergun data was estimated at $40 \mathrm{~m}$ per shot. FM35-12 common depth point (CDP) gathers were created with 66.66- $\mathrm{m}$ bin size, $33.33 \mathrm{~m}$ hydrophone group spacing with variable shot spacing $(\sim 50 \mathrm{~m} / \mathrm{shot})$, resulting in up to 120 -fold gathers. Stacking velocities from the seafloor to Horizon B were derived from 


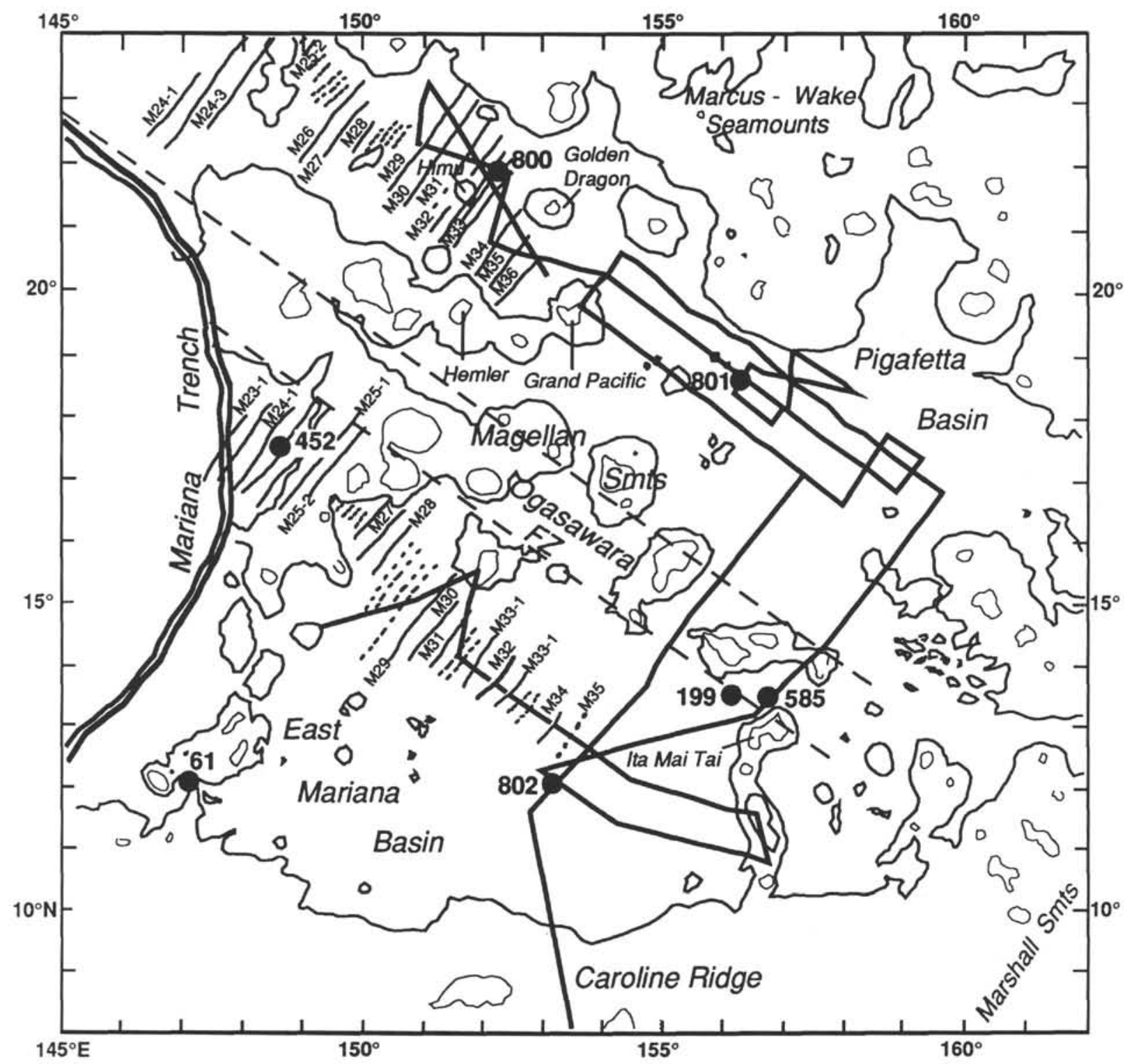

Figure 2. Bathymetry of the central western Pacific modified from Brenner and Angell (this volume) with location of selected DSDP sites and all of Leg 129 sites. Bold solid line indicates coverage of the FM35-12 and MESOPAC II regional seismic surveys. The 5500-m contour is highlighted and the 3000-m contour is shown as a lighter line. Magnetic anomalies are modified from Handschumacher and Gettrust (1985), Tamaki et al. (1987), and Handschumacher et al. (1988). The broad zone inferred for the location of the Ogasawara Fracture Zone is bounded by the dashed line.

semblance analysis of four adjacent CDP gathers at selected areas along each line and sub-Horizon B stacking velocities were derived from sonobuoy results.

\section{TECTONIC SETTING AND REGIONAL HISTORY}

The EMB and PB are defined as the area $\left(\sim 1 \times 10^{6} \mathrm{~km}^{2}\right)$ in our region of study where depths exceed $5500 \mathrm{~m}$ (Fig. 2) (Brenner and Angell, this volume). The EMB is bounded to the west-northwest by the Mariana Trench, to the southwest by the Caroline Ridge, and to the northeast by the northwest-trending Ogasawara Fracture Zone and Magellan Seamounts (Tamaki et al., 1987; Handschumacher et al., 1988) (Figs. 1 and 2). The PB is bounded to the northeast by the Kashima Fracture Zone and Marcus-Wake Seamounts and to the southeast by the Ogasawara Fracture Zone and Magellan Seamounts and extends to the northwest, where it terminates at the Bonin Trench.

In this paper age is assigned according to the geologic time scale of Harland et al. (1990). The available magnetic and seismic data suggest that the PB and EMB are underlain by oceanic crust of Late Jurassic to probably Middle Jurassic age (Figs. 1 and 2). The central parts of these basins are predicted to be Oxfordian to Callovian (anomalies M29 to M36; 157-162 Ma) and toward the southeast, within the Jurassic magnetic quiet zone (JQZ), the age of the crust may be as old as Bathonian to Bajocian (Middle Jurassic; 161-174 Ma). An alternative interpretation for the oldest anomalies in the EMB, as shown in Figure 2, is that they are symmetric about an abandoned spreading center at M32 time. Either interpretation would predict that Jurassic oceanic crust at Site 802 is older than M35 and younger than crust recovered at Site 801 ( 161-167 Ma). Nakanishi et al. (1989) calculate half-spreading rates of $64 \mathrm{~mm} / \mathrm{yr}$ for the oceanic crust formed in the PB between M21 and M25 using the time scale of Kent and Gradstein (1985) or $78 \mathrm{~mm} / \mathrm{yr}$ using Harland et al. (1990). The tholeiitic basalt recovered at Site 801 in the JQZ has been dated at $166.8 \pm 4.5 \mathrm{Ma}$ by whole rock ${ }^{40} \mathrm{Ar} /{ }^{39} \mathrm{Ar}$ incremental heating analysis (Pringle, this volume). A crustal age of $167 \mathrm{Ma}$ at Site 801 results in pre-M25 half-spreading rates of approximately $80 \mathrm{~mm} / \mathrm{yr}$, 


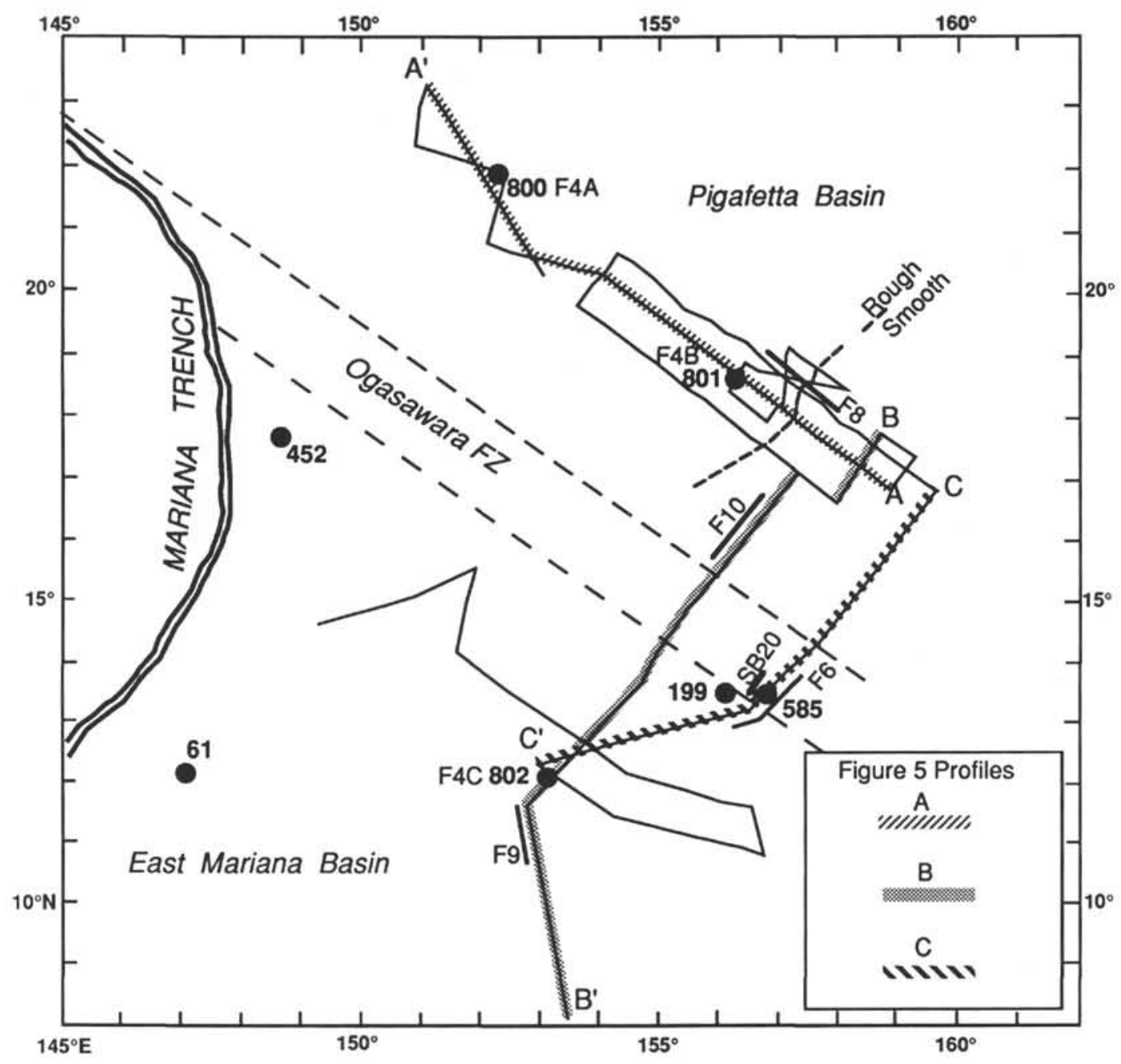

Figure 3. Solid line indicates coverage of the FM35-12 and MESOPAC II regional seismic surveys with location of Figures $4 \mathrm{~A}-\mathrm{C}, 6,8,9$, and 10, and sonobuoy 20 (SB20). The endpoints of composite profiles shown in Figure 5 are marked A-A', $\mathrm{B}-\mathrm{B}^{\prime}$, and $\mathrm{C}-\mathrm{C}^{\prime}$ and are highlighted as shown in the legend. Dots show DSDP/ODP site locations.

assuming constant rates of spreading and an M25 date of $155 \mathrm{Ma}$ (Harland et al., 1990). This spreading rate is comparable to the fastest half-spreading rates presently documented on the East Pacific Rise (80-90 mm/yr, MacDonald, 1982).

Reconstruction models of Pacific Plate motion, based on various references such as hotspot traces, paleomagnetism, magnetic anomaly skewness, and the sediment record of equatorial crossings, all indicate a general northward movement from southern to northern latitudes from the Late Cretaceous to Holocene (Lancelot and Larson, 1975; Jarrard and Clague, 1977; Sager and Pringle, 1988; Larson and Sager, this volume; Steiner and Wallick, this volume). Larson and Lowrie (1975) suggested that the plate moved from north to south during the latest Jurassic-earliest Cretaceous and thus might have crossed the equator twice. Paleomagnetic measurements of Leg 129 samples (Steiner and Wallick, this volume) and magnetic skewness analysis (Larson and Sager, this volume) indicate that the majority of the Pacific Plate (including Leg 129 sites) was south of the equator in the latest Jurassic but that its earliest motion did indeed have a southward component.

The latitudinal plate motion described above and the vertical motion caused by the subsidence of the plate as it cools with age influence the accumulation and distribution of pelagic sediments. The huge output of mid-plate volcanism during the middle Cretaceous, and a much smaller volume during the Tertiary, however, had the greatest influence over the subsidence history and the type, distribution, and volume of material delivered to these basins.

\section{WESTERN PACIFIC SEISMIC STRATIGRAPHY}

The seismic stratigraphy of large portions of the western Pacific including the PB and EMB consists of four units originally defined by Ewing et al. (1968): (1) an upper transparent layer (weakly reflective), (2) an upper opaque layer (highly reflective and/or well stratified), (3) a lower transparent layer, and (4) Horizon B.

Early Deep Sea Drilling Project (DSDP) investigations (e.g., Legs $6,7,17$, and 20) revealed the lithostratigraphic significance of the upper transparent and opaque layers in the western Pacific. The upper opaque layer has been correlated to the uppermost abundant chert in much of the North Pacific and the upper transparent layer has been recognized to correspond to a variety of lithofacies: pelagic clay in the west/central Pacific, turbidite sequences in the north and east, and biogenic oozes along the equator. Before DSDPLeg 32 there was little direct knowledge of the lower transparent seismic unit and Horizon B in the oldest portions of the Pacific, and it was not until Leg 129 that these two deepest seismic facies were directly sampled in the EMB and PB.

This paper will concentrate primarily on sedimentary stratigraphy overlying the Horizon B reflection within the EMB and PB and will 
emphasize the correlation of seismic and lithostratigraphy using the drilling results from Leg 129. A full description of basinwide variability of crustal stratigraphy, including Horizon B, is presented in Abrams et al. (in press).

\section{Leg 129 Site Review}

At the sites drilled during Leg 129 we penetrated and recovered material correlated to all four general seismic units of Ewing et al. (1968), including Horizon B. The seismic stratigraphy at Leg 129 Sites is summarized in Figure 4A-C.

Site 801 , located in the southeast PB, was the first and so far only location where Jurassic sediments and oceanic crust have ever been recovered in the Pacific. The oldest sediments recovered were claystone/radiolarite (Callovian-Bathonian, 157-166 Ma). Horizon B at 462 meters below seafloor (mbsf) corresponds to the top of oceanic crust, radiometrically dated at $\sim 167 \mathrm{Ma}$, and is overlain by Middle Jurassic to Lower Cretaceous pelagic sediments (radiolarite/clay) beneath a thick sequence of volcanogenic turbidites deposited after mid-Valanginian time through the Albian-Cenomanian ( 135-97 Ma). Site 800, located in the northwest PB, reached Horizon B at 498 mbsf. Horizon B corresponds to dolerite sills radiometrically dated at $\sim 120 \mathrm{Ma}$ below earliest Cretaceous pelagic sediments and a thick sequence of Aptian (112-124.5 Ma) volcanogenic turbidites. Site 802 in the EMB penetrated Horizon B at 509 mbsf, sampling basalt flows and pillow units, radiometrically dated at $\sim 114$ $\mathrm{Ma}$, beneath a sedimentary cover that consists almost exclusively of redeposited sediments of Aptian to Pliocene age (124.5-5.2 Ma) (radiometric dates from Pringle, this volume).

\section{DSDP Site Review}

DSDP Site 585 on the eastern margin of the EMB is located over the anomalously deep trough of the Ogasawara Fracture Zone and reached upper Aptian volcanogenic turbidites at $893 \mathrm{mbsf}$, approximately $260 \mathrm{~m}$ short of high-velocity igneous basement (crust or massive volcanism) (Abrams et al., in press). Redeposited volcanogenic and biogenic material dominate the sedimentary section and record the growth, subsidence, and erosion of the surrounding Magellan Seamounts from Aptian to Holocene. The uppermost $\sim 485 \mathrm{~m}$ (units I-IV) are considered comparable to the section drilled at DSDP Site 199.

DSDP Site 199, located $\sim 75 \mathrm{~km}$ west of DSDP Site 585 in the EMB, terminated at $456 \mathrm{mbsf}$ in brown tuff beneath upper Campanian chalk/clay/chert to upper Paleocene chert/chalk at $285 \mathrm{mbsf}$. The uppermost unit consists of zeolitic clay, microfossil ooze, and a few ash layers all younger than late Oligocene. DSDP Leg 89 investigators (i.e., Site 585) reinterpreted these sediments as turbidites deposited below the carbonate compensation depth $(\mathrm{CCD})$ along with background pelagic accumulation.

DSDP Site 61 , located more than $600 \mathrm{~km}$ due west of Site 802 (Fig. 2), penetrated basalt flows interlayered with Santonian-upper Campanian sediments ( 86-80 Ma) at 93 mbsf. The basalt correlates to a prominent reflection which overlies a deeper weak event believed to be the top of oceanic crust (Shipboard Scientific Party, 1971). The sediment that overlies basalt consists of minor Upper Cretaceous chert, zeolitic clay, and radiolarian ooze of Paleocene to Miocene age and younger zeolite clays and diatom oozes. The available seismic data across DSDP Site 61 is inadequate in quality and coverage, and cannot be correlated with the seismic stratigraphy of most of the EMB.

\section{SEISMIC OBSERVATIONS}

The results of our regional seismic profiles are illustrated in three cross sections across both the EMB and PB (Figs. 5A-C; location in Fig. 3) and are accompanied by several key seismic reflection examples. The cross sections were created by digitizing distinctive reflec- tion surfaces which seemed to maintain unique characteristics (i.e., seismic facies) over basinwide distances. The selected horizons include the seafloor, the shallowest abundant chert/porcellanite/clay or chert/chalk, mid-Cretaceous basaltic sills/flows (smooth, flat-lying Horizon B), and the top of Jurassic oceanic crust (rough, high-relief Horizon B). In the EMB the lithofacies significance of these distinct seismic horizons and the intervals which they bound is based on the lithologies recovered at Site 802 (Fig. 4C) in the center of the basin, DSDP Sites 199 and 585 (Fig. 6) on the far eastern edge, as well as DSDP Site 61 at the far western edge, while the more variable seismic stratigraphy of the PB is interpreted from the results of ODP Sites 800 and 801 (Figs. $4 \mathrm{~A}$ and $4 \mathrm{~B}$ ).

\section{Sediment Velocities}

Sediment velocities, based on velocity analysis of four contiguous CDP gathers from the 3.3-km-long 96-channel streamer, ranged from 1.6 to $3.0 \mathrm{~km} / \mathrm{s}$, usually increasing with depth. This range in velocities is similar to velocities derived from $T^{2} / \mathrm{X}^{2}$ sonobuoy solutions in the northwest Pacific and those measured during DSDP Legs 20, 32, and 89 (Heezen, MacGregor, et al., 1973; Larson, Moberly, et al., 1975; Moberly, Schlanger, et al., 1986). This range in velocities is also consistent with modeled reflections within the sediment layer from sonobuoys collected during our investigations (Abrams et al., in press).

Average velocities of the intervals bounded by the above horizons are estimated from differences in two-way traveltime and drilled thicknesses. The average velocity for the entire sedimentary section above Horizon B is $2.0 \mathrm{~km} / \mathrm{s}$ at both Sites 800 and 801 and $\sim 1.9 \mathrm{~km} / \mathrm{s}$ at Site 802. Downhole sonic log measurements (obtained for only a portion of the sedimentary section at each site) indicate systematically higher average velocities and provide constraints on small verticalscale lithologic variations (Fisher et al., this volume). The average velocities presented here are not used as lithologic discriminants but are useful in determining thickness variations of seismic lithofacies over lateral scales of 100 to $1000 \mathrm{~km}$.

\section{Horizon B}

Horizon B is characterized as a single or two closely spaced, very high amplitude, typically smooth reflector(s) when imaged with either the FM35-12 airgun or MESOPAC II watergun source. Horizon B often appears as acoustic basement, in that where it is present, deeper reflections are usually not observed with any consistency. This distinct reflective horizon is associated with the onset of high velocities $(>3.8 \mathrm{~km} / \mathrm{s}$ ) (Abrams et al., in press), and we believe it is comparable in acoustic character to the unusually smooth basement observed in parts of the western North Atlantic and Caribbean Basin that was designated as Horizon B (Ewing et al., 1967; Edgar, Saunders, et al., 1973; Houtz and Ludwig, 1977). In this context, Horizon B will always refer to a high-velocity horizon; its reflection character and stratigraphic position will determine if this horizon is interpreted as the top of sills/flows that overlie true oceanic crust, or Jurassic-age oceanic crust with no such massive igneous overburden. Horizon B can be characterized by two end-member modes: (1) as a relatively high relief (50-100 m over tens of kilometers), lower reflection amplitude, diffractive ("rough") surface which always appears as acoustic basement and is interpreted as the top of oceanic crust, and (2) as a flat-lying, high-reflection amplitude, semicontinuous surface which most often appears nondiffractive ("smooth"), does not necessarily appear as acoustic basement, and is interpreted as sills/flows overlying oceanic crust. A map view of the acoustic character of Horizon B and its interpretation is presented along the seismic track lines in Figure 7 and in cross section in Figure 5. These figures indicate that there are extensive areas in the northwest PB where the acoustic character does not clearly fall within the above defined modes and/or these end-member reflection characteristics alternate over distances 

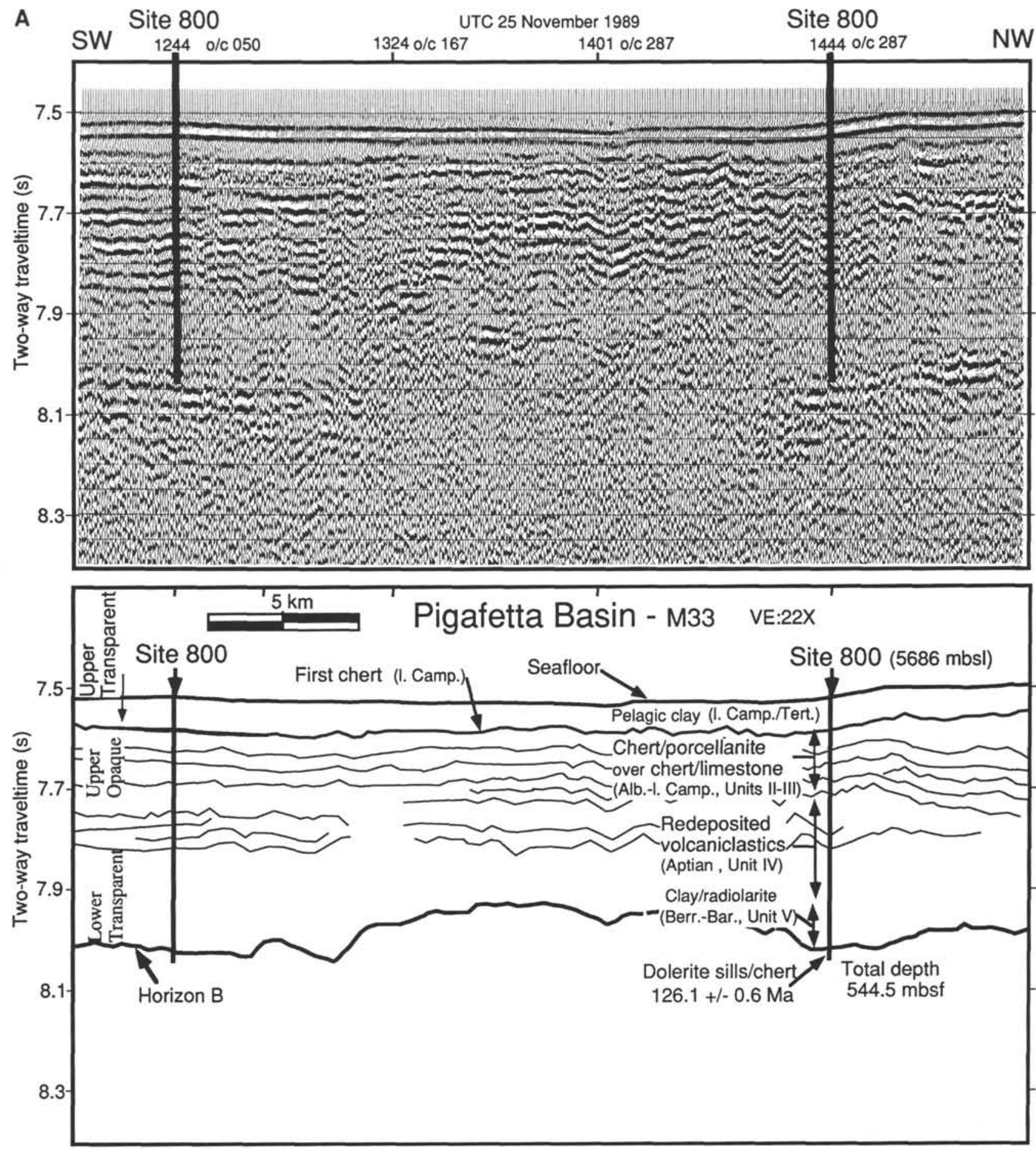

Figure 4. Summary of seismic stratigraphy at Leg 129 Sites 800 (A), 801 (B), 802 (C) showing generalized correlations with lithologic units, ages and depths, with emphasis on key reflective horizons such as igneous basement and first chert (Lancelot and Larson et al., 1990). Radiometric ages are from Pringle (this volume). Site 800 imaged with SCS waterguns (two $80 \mathrm{in}^{3}{ }^{3}$ ) obtained on approach to Site 800 during Leg 129 . Seismic profiles shown for closest possible approach (CPA) to Sites 801 and 802 during MESOPAC II (six 80 -in. ${ }^{3}$ waterguns). These near-channel records were processed and displayed with the following parameters: mute, band-pass filter $25-100 \mathrm{~Hz}, 2$-trace mix, water-velocity F/K migration, 500-ms AGC, and vertical exaggeration (VE) of $\sim 22 \times$ at $1.5 \mathrm{~km} / \mathrm{s}$. O/C $=$ on course, UTC $=$ Universal Time Coordinated. 

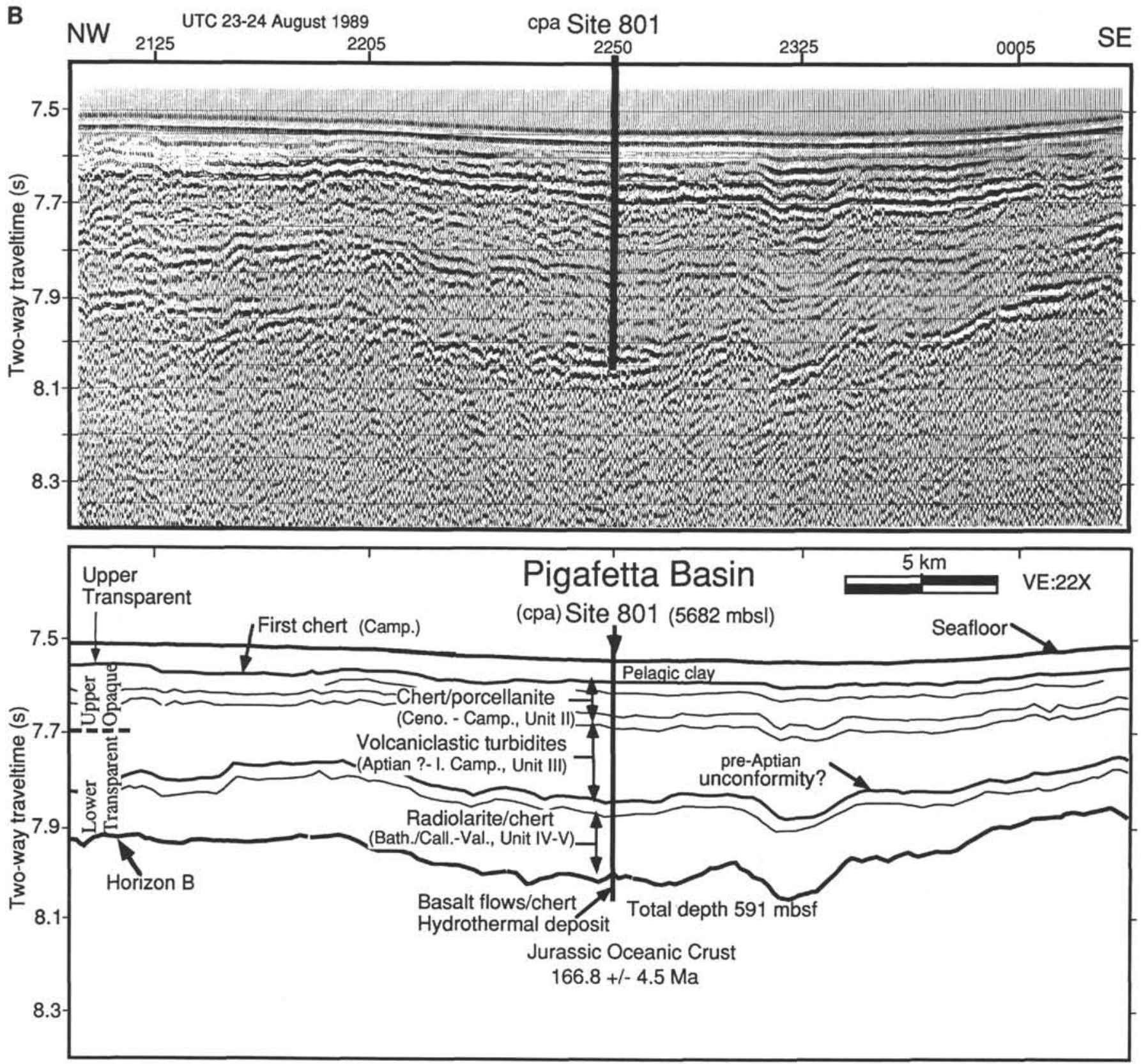

Figure 4 (continued).

of only tens of kilometers and as a result these areas have been more tentatively interpreted as the top of oceanic crust with possible sill/flow overburden (Abrams et al., in press). In contrast, Horizon B throughout the southeast $\mathrm{PB}$ and entire EMB, including the Caroline Ridge, is interpreted as the top of mid-Cretaceous flows and sills which are less than $400 \mathrm{~m}$ thick (probably $\sim 100 \mathrm{~m}$ ) and no older than Aptian (<124.5 Ma). Weak discontinuous reflections $100-150 \mathrm{~ms}$ below Horizon B have been interpreted as the top of Jurassic oceanic crust in the EMB (Abrams et al., in press). Finally, Horizon B at Site 801 unquestionably represents the top of oceanic crust of Jurassic age. Southwest of Site 801 Horizon B becomes markedly flat-lying and smooth. This distinct change in seismic character termed "the rough/smooth boundary" marks the lateral extent of continuous midCretaceous massive igneous units overlying Jurassic oceanic crust and sediment (Fig. 8).

\section{Lower Transparent Unit}

Immediately overlying Horizon B is the lower transparent unit ( 8.1-8.4 seconds two-way traveltime [s TWT] at EMB Site 802), which is characterized by low-amplitude, more widely separated and discontinuous reflectors, making this sequence distinctly transparent on both airgun and watergun seismic records (Fig. 4C). These reflections are flat-lying and thin where Horizon B rises (300 milliseconds below seafloor [ms bsf]) and appear to onlap the sill/flow surface (Horizon B), where it is disrupted by an abrupt offset occurring along the lower slope of the Caroline Ridge south of Site 802 (Fig. 9), which suggests that the lower transparent unit is not dominantly pelagic drape.

The lower transparent unit in the central EMB correlates with the sequence of redeposited upper Aptian calcareous claystone and radiolarite penetrated at Site 802 (460 to $509 \mathrm{mbsf}$ ), as well as the lower 

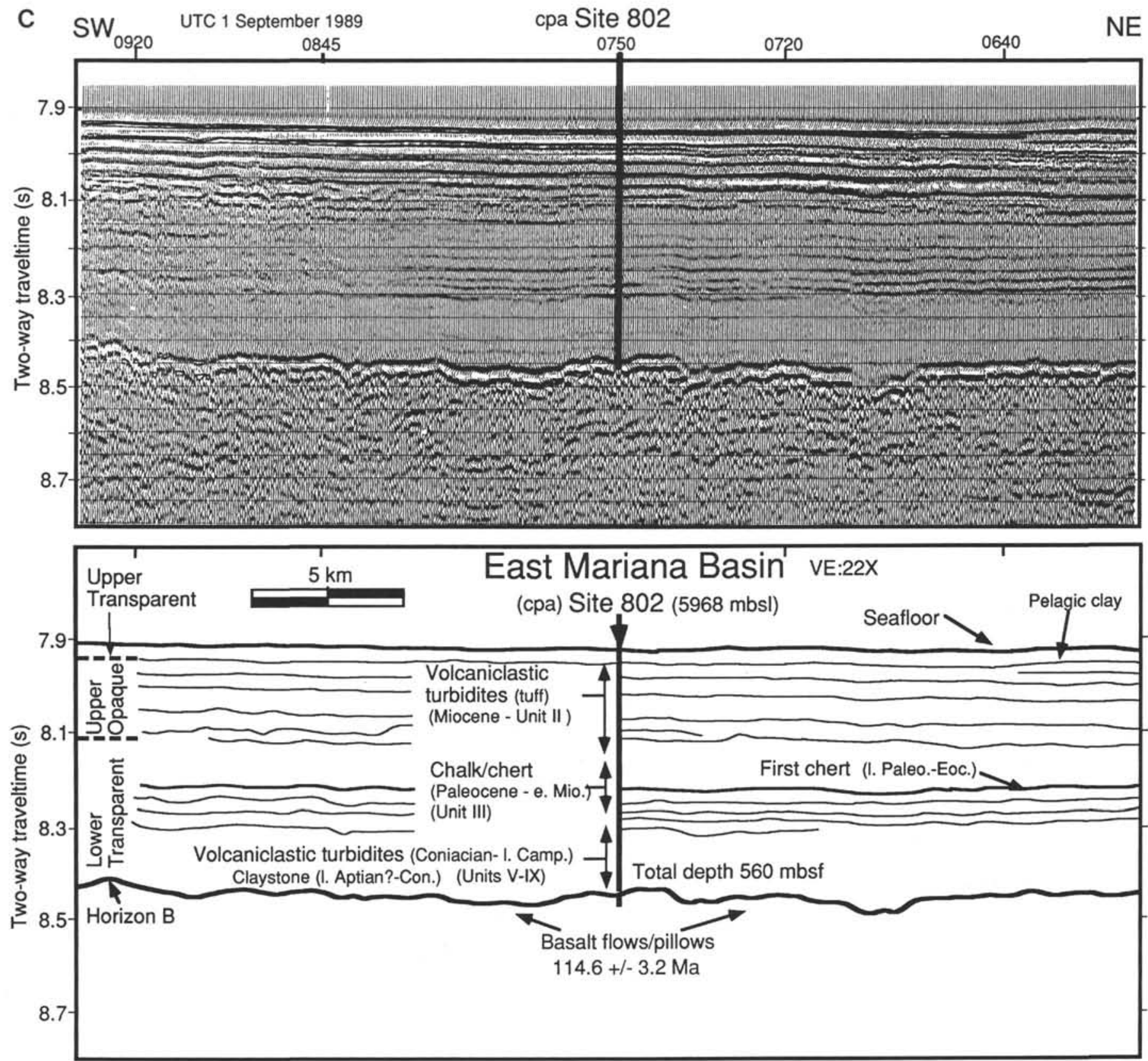

Figure 4 (continued).

portion of the Coniacian to Campanian volcaniclastic turbidites (388 to $360 \mathrm{mbsf}$ [Fig. 4C]). The moderate-amplitude reflections that divide the lower transparent unit in half at approximately $8.2-8.3 \mathrm{~s}$ TWT are thought to correspond to the increased occurrence of chert within a chalk-dominated sequence overlying a transition zone that contains volcaniclastic turbidites, calcareous claystone, and porcellanite of late Campanian to Eocene age. The top of this unit at 200-300 mbsf (Figs. 4C and 5A-C) can be identified basinwide and is correlated to the first chert of similar age at DSDP Site 199 (285 mbsf) and DSDP Site 585 ( $>256 \mathrm{mbsf}$ ). This unit appears to drape onto the immediately surrounding seamounts (Fig. 6) and there is a much greater thickness of Upper Cretaceous to middle Eocene chalk and chert at DSDP Sites 199 and 585 at the eastern edge of the EMB than at Site 802 (Heezen, MacGregor, et al., 1973; Moberly, Schlanger, et al., 1986; Lancelot, Larson, et al., 1990) (Figs. 5C, 6).
The relatively transparent interval above the first chert at $\sim 8.2 \mathrm{~s}$ TWT and below the onset of high-amplitude reflections at $\sim 8.05 \mathrm{~s}$ TWT corresponds to tuff intercalated with redeposited calcareous claystone and chalk between approximately 167 and $300 \mathrm{mbsf}$ at Site 802.

In the $\mathrm{PB}$, the lower transparent unit ranges from 250 to $460 \mathrm{~ms}$ bsf (7.68-8.00 s TWT at Site 801 [Fig. 4B]) and may extend as high as $140 \mathrm{~ms}$ bsf. This layer appears to thin to the southeast of Site 801 as the underlying Horizon B rises in the section and changes to its more typical flat-lying, smooth appearance. The lower transparent unit sometimes includes a distinct high-amplitude, continuous reflection that mimics the underlying relief and appears to be a draping deposit. In the immediate vicinity of Site 801 this high-amplitude reflection at $310 \mathrm{~ms}$ bsf appears to divide the lower transparent unit in two (Fig. 4B) and, in other instances, it seems to mark the base of 

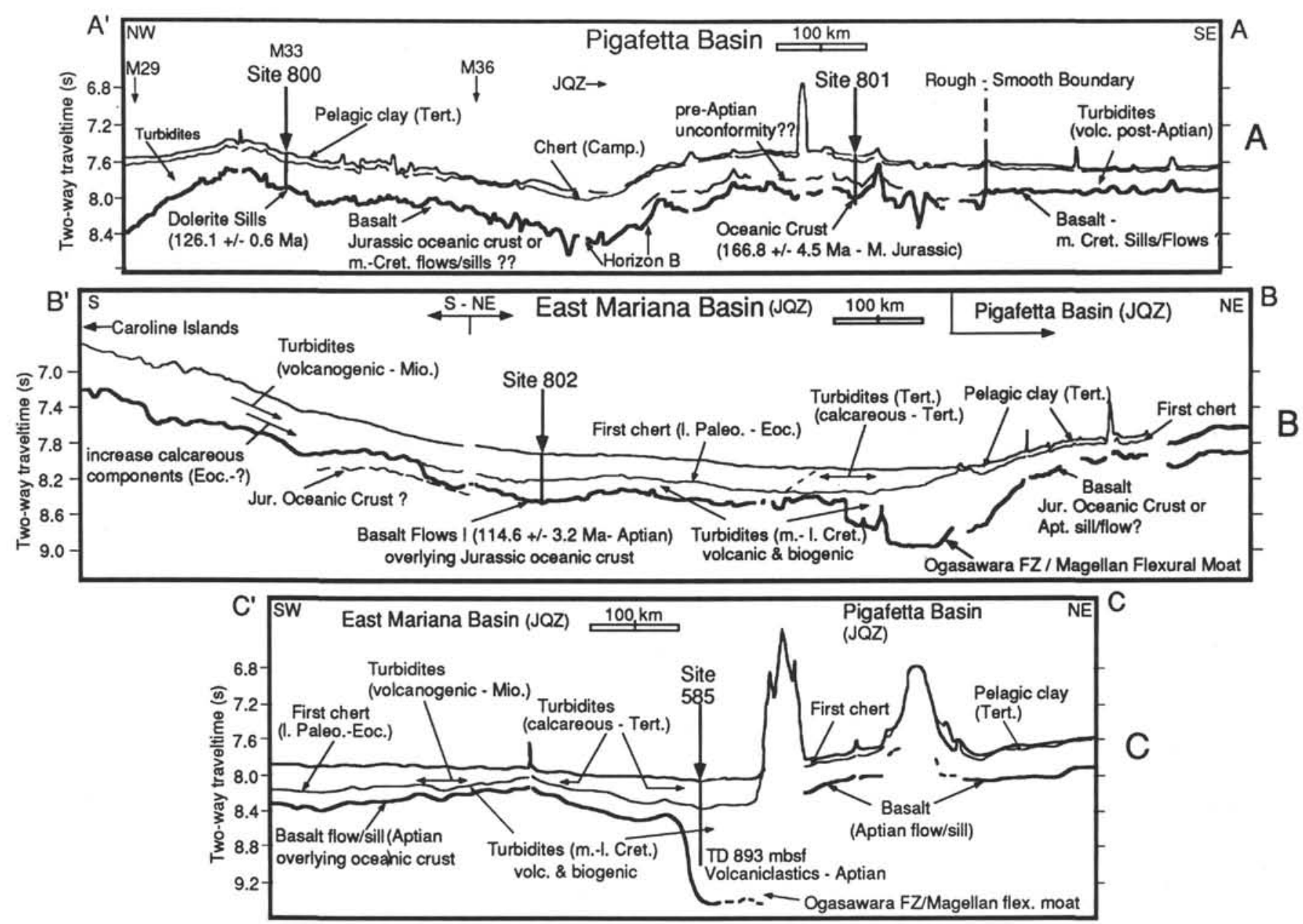

Figure 5. Three 900- to 1300-km-long profiles showing selected reflections digitized from both MCS airgun and near-channel watergun data (see Fig. 3 track chart for locations of profiles $\mathrm{A}-\mathrm{A}^{\prime}(\mathbf{A}), \mathrm{B}-\mathrm{B}^{\prime} \mathrm{m}(\mathbf{B})$, and $\mathrm{C}-\mathrm{C}^{\prime}(\mathbf{C})$. The deepest horizon (Horizon $\mathrm{B}=$ heavy line) always represents the top of high-velocity igneous material. This horizon is characterized and interpreted from direct sampling at three widely separated ODP sites, from reflection character, and from velocity structure. The middle horizon always represents the top of the first chert-porcellanite and is interpreted as a time-transgressive horizon that marks the passage of the Pacific Plate beneath the equatorial zone of high productivity (Heezen et al., 1973; Lancelot and Larson, 1975). The top horizon represents the seafloor. Note the depth difference between the PB and EMB $(\sim 300 \mathrm{~m})$ and the uniformly flat Horizon B (even at VE of $\left.133^{\prime}\right)$ in the EMB and southeast PB compared to the higher relief (at long and short wavelengths) Horizon B of the PB northwest of the rough-smooth boundary. Radiometric ages are from Pringle (this volume). TD $=$ total depth; JQZ = Jurassic magnetic quiet zone.

an overlying opaque layer or becomes part of an opaque layer that extends all the way to basement (e.g., left side of Fig. 4B). This variation in acoustic character for the interval directly overlying Horizon B is observed throughout the PB but, in general, the lower transparent layer is best developed where Horizon B is not shallow in the section (e.g., 200-300 ms bsf). It appears most distinct and continuous in the central portion of the JQZ between Site 801 and approximately M36 (Fig. 5A) but is poorly developed along the southwest edge of the PB (right side of Fig. 10).

The lower transparent unit at Site 801 correlates with the thin (18 m) sequence of Callovian-Bathonian red radiolarite and claystone and pre-Aptian brown radiolarite ( $310-453 \mathrm{mbsf})$, as well as the lower portion of the Aptian?-Albian volcaniclastic turbidites (about 185 to 310 mbsf) (essentially depositional stages 1-3 of Karpoff, this volume). The situation at Site 800 is similar; however, the clay/radiolarite pelagic section is much thinner and gives way to volcaniclastic debris flows earlier, in the Aptian (Fig. 4A). The critical difference for Leg 129 investigators is that all the Upper Jurassic pelagic deposits, as well as a portion of the Berriasian, are covered/intruded by a dolerite sill in which Site 800 terminated.
The high-amplitude reflection that divides the transparent layer in half at $310 \mathrm{~ms}$ bsf at Site 801 (Fig. 4B) is thought to correspond to an unrecovered, unusually well-lithified horizon-perhaps a massive chert layer or "hard ground" as inferred from an abrupt drilling rate decrease and downhole log response (Shipboard Scientific Party, 1990b). This horizon marks the transition from nonvolcanogenic lithologies below $\sim 318 \mathrm{mbsf}$ (mid-Valanginian) to an overlying sequence dominated by volcanogenic turbidites no older than Aptian (Ogg et al., this volume). The reflection that corresponds to this Early Cretaceous unconformity is tentatively traced $200 \mathrm{~km}$ northwest of Site 801 and is not noted at Site 800 (Figs. 4A and 5A). To the southeast of Site 801 the lower transparent unit is absent and we expect that volcanogenic turbidites, no older than Aptian age, directly overlie Aptian age sills/flows (Horizon B), which in turn mask Jurassic-Lower Cretaceous sediment and oceanic crust.

\section{Upper Opaque Unit}

In the EMB the sequence from the seafloor down to approximately $100-200 \mathrm{~ms}$ bsf is comparable to that described by Ewing et al. (1968) 

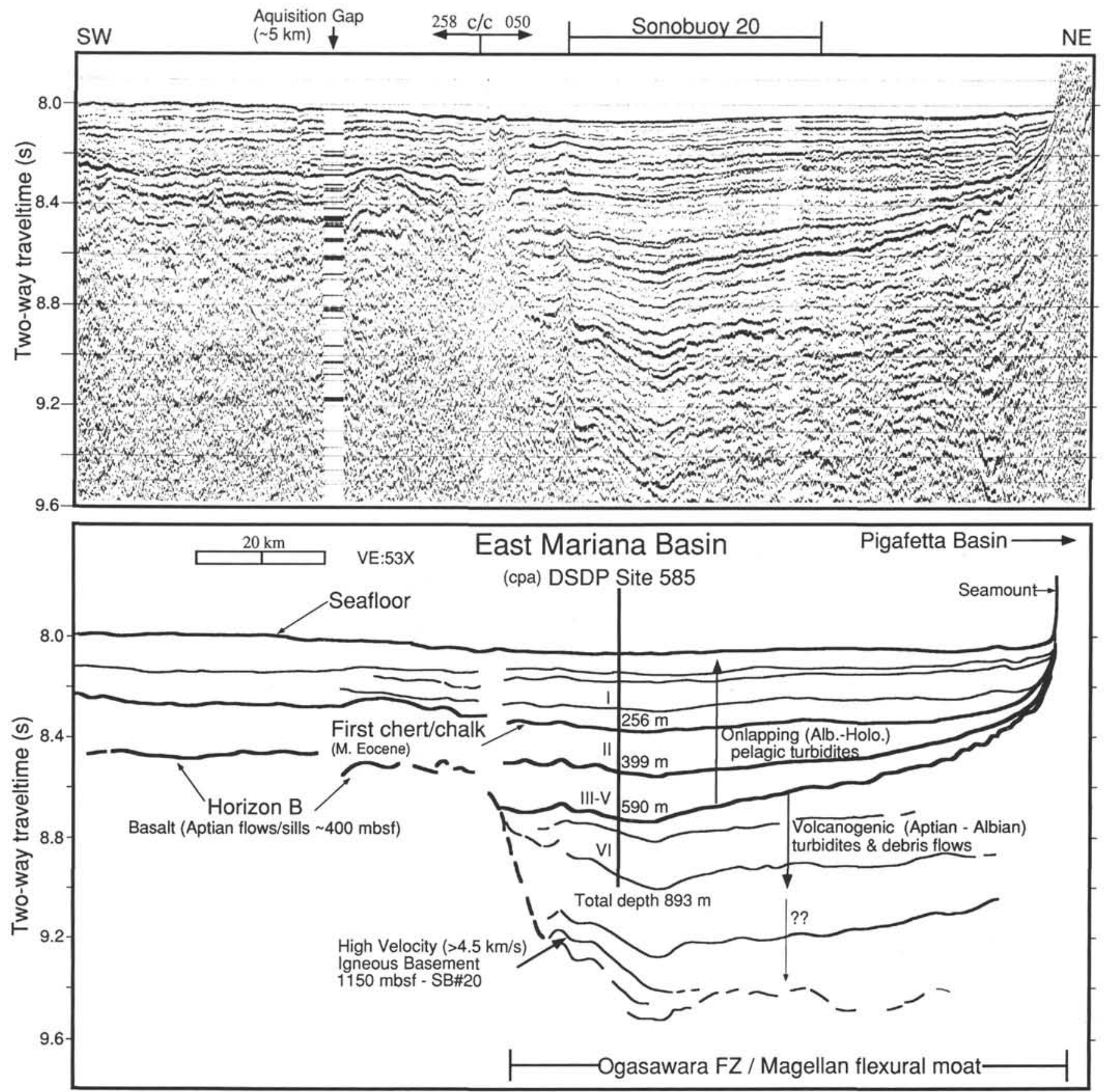

Figure 6. FM35-12 MCS airgun profile across DSDP Site 585 and the inferred location of the Ogasawara Fracture Zone. Roman numerals indicate lithologic units as presented in Moberly, Schlanger, et al. (1986). The chert/chalk horizon can be traced basinwide and is interpreted as a time-transgressive horizon marking the passage of the Pacific Plate beneath the equatorial zone of high productivity (Heezen et al., 1973; Lancelot and Larson, 1975). High-velocity Horizon B deepens over a 20- to 40-km range from approximately 300 to $600 \mathrm{mbsf}$ in the majority of the EMB to over 1150 mbsf at DSDP Site 585. Comparable deepening of the Horizon B reflector over a much larger range $(\sim 120-160 \mathrm{~km})$ is observed along MESOPAC II line 18 shown in Figure 10. The processing and display parameters are as follows: pre-stack spike deconvolution, 120 -fold stack, band-pass filter $20-60 \mathrm{~Hz}, \mathrm{~F} / \mathrm{K}$ migration, $500-\mathrm{ms} \mathrm{AGC}$, and VE $=\sim 53 \times$ at $1.5 \mathrm{~km} / \mathrm{s}$.

as the "upper opaque layer" (Fig. 4C). This interval contains closely spaced, moderate-to-high amplitude reflections that are traceable for 30 to $50 \mathrm{~km}$. This uppermost unit is distinct in that reflections onlap basement highs, including a large unnamed Magellan seamount to the north and Ita Mai Tai Guyot to the south, and tends to thicken in minor lows and thin over minor highs. This upper unit, however, becomes distinctly transparent on processed FM35-12 airgun records $\sim 250 \mathrm{~km}$ east of Site 802, including the area south of DSDP 199.
In the PB the lower transparent unit is bounded on top by a distinctly higher amplitude, more continuous sequence of reflections that appear to drape over underlying relief. This unit appears to maintain a fairly uniform thickness throughout extended portions of the PB and appears to replace the lower transparent unit altogether where the Aptian age sills/flows (Horizon B) are particularly shallow (e.g., southeastern PB 220 to $300 \mathrm{~ms}$ bsf [right side of Figs. 8 and 10]). This series of three to four continuous, high-amplitude reflectors 


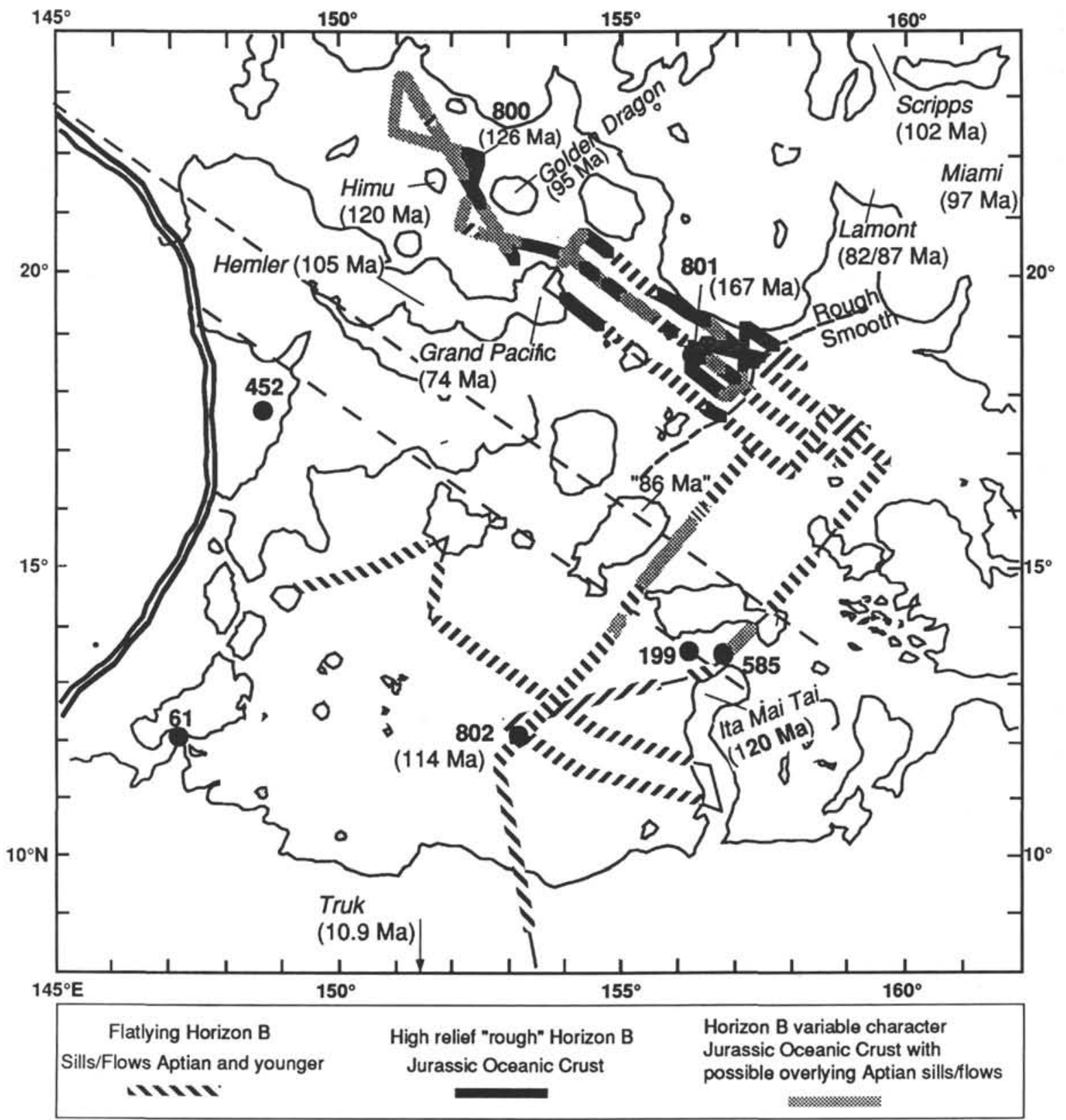

Figure 7. Simplified bathymetry ( $5500 \mathrm{~m}$ contour is shown) of the central western Pacific modified from Brenner and Angell (this volume). The reflection character of Horizon B and its interpretation are indicated along track from Abrams et al. (in press). The oceanic crust in the entire EMB and southeast PB $\left(\sim 500,000 \mathrm{~km}^{2}\right)$ is overlain by sills/flows of Aptian age or younger. Only a few restricted areas in the PB are confidently interpreted to contain Jurassic-age oceanic crust with no massive igneous overburden. Horizon B in extended areas (primarily in the PB) is more tentatively interpreted as Jurassic-age oceanic crust with Aptian age or younger sill/flow overburden possible. Radiometric ages of basalt are given in Ma for Leg 129 Sites from Pringle (this volume), and for seamounts from Ozima et al. (1983), Keating et al. (1984), Pringle (pers. comm., 1991), Pringle (1992), and Winterer et al. (in press). Note: Grand Pacific is referred to as "D4" in Ozima et al. (1983).

is distinguished from the comparable seismic facies in the EMB by the greater continuity of individual reflectors and the fact that the majority of this sequence appears as a draping deposit rather than the basin-filling sequence observed in the EMB. In areas of relatively high relief Horizon B these uppermost reflectors show corresponding, but muted relief (Fig. 4B at 2325 Universal Time Coordinated).

The upper opaque unit in the central portion of the EMB corresponds to mid-Pliocene-lower Miocene redeposited tuff and minor interbedded pelagic claystone at Site 802 and maintains a fairly uniform thickness of 150-200 m throughout the basin (Shipboard Scientific Party, 1990c). The high-amplitude, semicontinuous reflec- tions that characterize this interval are interpreted to arise from impedance contrasts between alternating zones of variably cemented coarse-grained volcanic sandstone and fine-grained volcanic siltstone/claystone. To the south of Site 802 along a MESOPAC II track heading south out of the EMB toward the Caroline Ridge the upper opaque unit (Miocene tuff) thickens and directly overlies the rising Horizon B (mid-Cretaceous flow/sill). The semicontinuous reflections of the upper opaque unit (Miocene tuff) downlap toward the basin and eventually thin to the nearly constant thickness of $200 \mathrm{~ms}$ observed in the central EMB (Figs. 4A, 5B, 9). Along the eastern margin of the EMB, at Sites 199 and 585, this uppermost seismic unit 

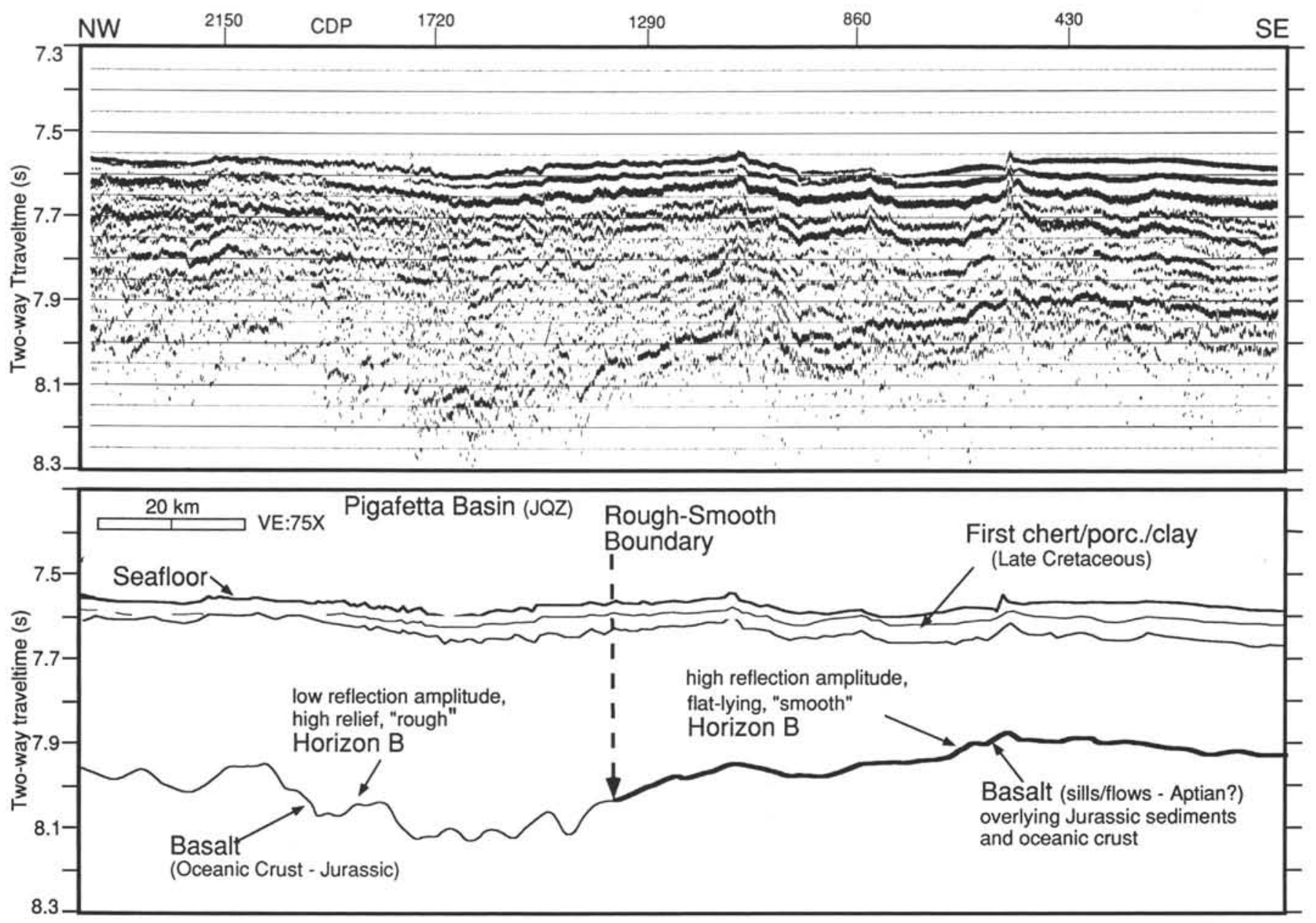

Figure 8. FM35-12 MCS airgun profile in the JQZ of the PB along an inferred flowline course and displayed at true relative amplitude. The continuous, flat-lying (at a VE of 75×), and high-amplitude Horizon B reflection southeast of the rough-smooth boundary deepens and appears to be contiguous with an undulating, diffractive, and lower reflection amplitude "rough" Horizon B. The "rough" Horizon B correlates to the top of middle Jurassic-age oceanic crust (e.g., Site 801) and the "smooth" horizon is interpreted as basalt sills and flows of Aptian age overlying the unimaged top of oceanic crust. The rough/smooth boundary appears on all five of our tracks that cross this area, and a comparable boundary is not apparent in the EMB. We suggest that the boundary marks the limit of semicontinuous Aptian flows/sills. The processing and display parameters are as follows: pre-stack spike deconvolution, 120 -fold stack, band-pass filter $8-25 \mathrm{~Hz}, \mathrm{~F} / \mathrm{K}$ migration, and VE of $\sim 75 \times$ at $1.5 \mathrm{~km} / \mathrm{s}$.

appears much more transparent and it certainly corresponds to the Tertiary calcareous turbidites that were recovered at DSDP Site 199 and easily washed through at DSDP Site 585 (Figs. 6, 5B, and 5C) (Heezen, MacGregor, et al., 1973; Moberly, Schlanger, et al., 1986). The transition from these "soft" calcareous turbidites to the well-indurated tuffaceous volcaniclastic turbidites recovered in the central EMB may be marked by the change in acoustic character (FM35-12 airguns) of the upper opaque unit (i.e., transparent = calcareous to opaque $=$ tuff). In the vicinity of DSDP Site 585 this interval does not thicken and is observed to onlap the middle Eocene chert/chalk reflector as it drapes onto and merges with the surrounding seamounts (Fig. 6, right side). The upper opaque reflections are also observed to onlap the chert/chalk horizon as it rises in section $(<100 \mathrm{~ms}$ bsf) along MESOPAC II line 18 across the eastern margin of the EMB (Fig. 5B). Drilling results from DSDP Sites 59, 61, and 452, located on the far western to northwestern margin of the EMB (Fig. 2), indicate that the flat-lying reflections composing the upper opaque unit correlates to chert/porcellanite/clay of Late Cretaceous age.

In the northwest PB the transition from brecciated, poorly bedded debris flows to coarse-grained turbidites, along with the appearance of nannofossils at approximately $351 \mathrm{mbsf}$, correlates to a change from lower transparent to upper opaque seismic facies at Site 800 (Fig. 4A) (Shipboard Scientific Party, 1990a). The lowermost section of the upper opaque unit is characterized by the highest amplitude, most continuous reflections that change to lower amplitude, less continuous events upsection. The subtle change in seismic character that occurs within the upper opaque unit is clearly correlated to the transition from redeposited volcanogenic material with intervals of high silicon content (about 219 to $300 \mathrm{mbsf}$ ) to a sequence of pelagic carbonate and silica-rich sediments (between 78 and 219 mbsf) (Shipboard Scientific Party, 1990a). The most discontinuous and diffuse (but still high-amplitude) reflections are associated with the Turonian to upper Campanian clay/porcellanite/chert sequence between 38 and 78 mbsf.

At Site 801 a transition zone that consists of middle to upper Albian volcaniclastic turbidites and interbedded pelagic material at approximately $193 \mathrm{mbsf}$ correlates to the relative increase in reflection amplitude that marks the change from lower transparent to upper opaque seismic facies. These high-amplitude reflections also encompass the overlying pelagic interval where impedance contrasts occur between interbedded chert/porcellanite and pelagic clay of Cenomanian to Campanian age (Fig. 4B). 

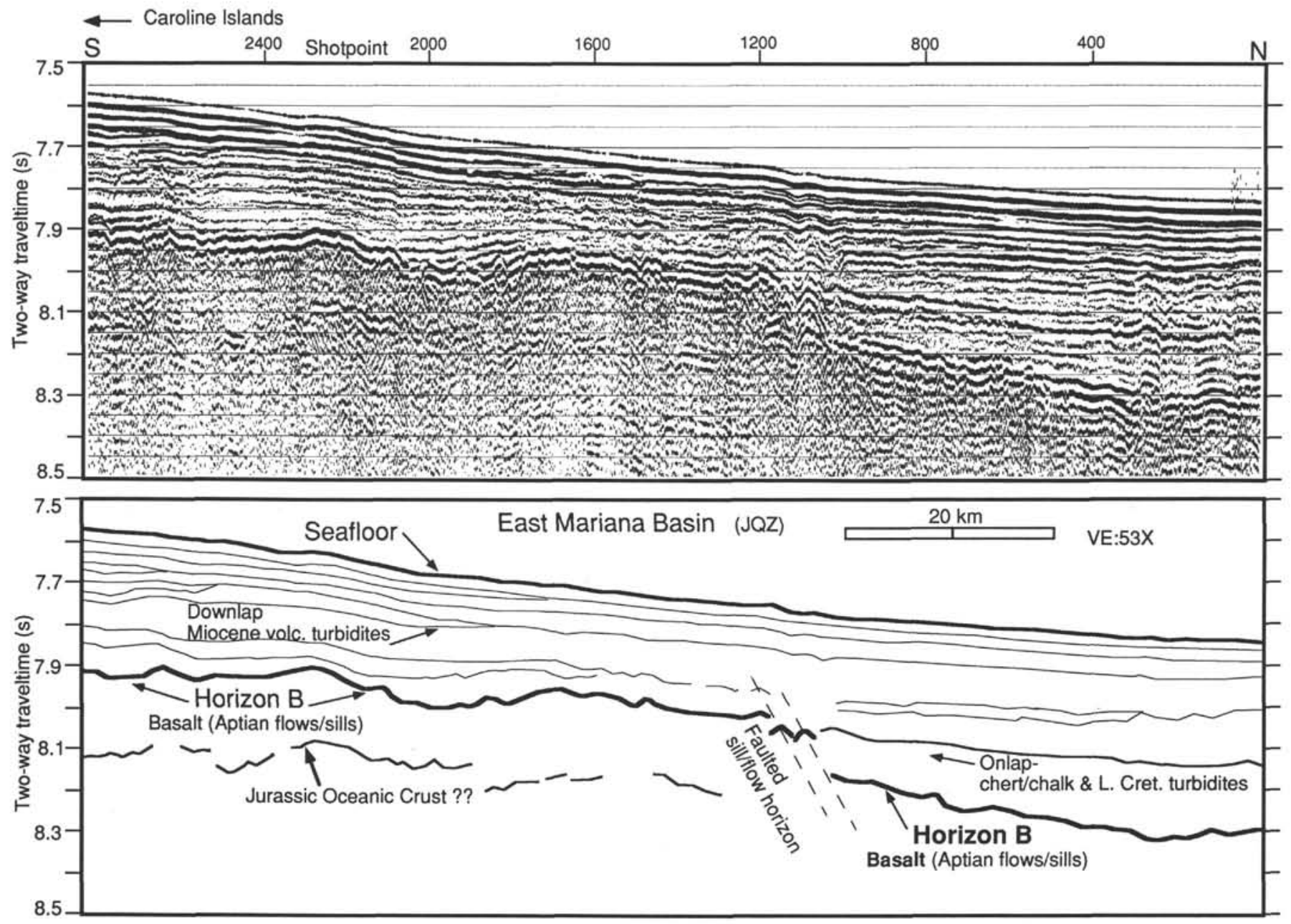

Figure 9. MESOPAC II SCS watergun profile in the southern EMB. Site 802 penetrated extrusive basalt dated at $114.6 \pm 3.2$ m.y. (Pringle, this volume) beneath Aptian-age sediment, this horizon is onlapped by upper Paleocene chert/chalks and underlying Upper Cretaceous turbidites, indicating they may be derived from the Magellan Seamounts rather than the Caroline Ridge. The basalt horizon penetrated at Site 802 continues up onto the Caroline Ridge. The high-amplitude continuous reflections that are correlated to the Miocene-age volcanogenic turbidites recovered at Site 802 are observed to thicken to the south and downlap toward the EMB, which indicates, along with their age, that the Caroline Islands are the most likely source. A weak, semicontinuous, relatively high-relief horizon imaged beneath the rising flow/sill horizon may represent the top of oceanic crust. This near-channel record is processed and displayed with the following parameters: mute, 2-trace mix, band-pass filter $25-100 \mathrm{~Hz}$, water-velocity F/K migration, 500-ms AGC, and VE of $\sim 53 \times$ at $1.5 \mathrm{~km} / \mathrm{s}$

\section{Upper Transparent Unit}

This acoustically transparent layer is less than $100 \mathrm{~m}$ thick over much of the North Pacific from $15^{\circ}$ to $45^{\circ} \mathrm{N}$ (Ewing et al., 1968). The upper transparent unit in the EMB and PB extends from 0 to approximately $30 \mathrm{~ms}$ bsf at Site 802 and from approximately $100 \mathrm{msbsf}$ to less than $30 \mathrm{~ms}$ bsf throughout the majority of the PB. This interval is often absent altogether and appears to be scoured away, and the surrounding thicker accumulations are interpreted as levee deposits. When present, this interval appears to drape over irregularities, mirroring the uppermost high-amplitude reflections of the upper opaque unit. This interval is best displayed on $3.5-\mathrm{kHz}$ records, but is also apparent on SCS and MCS records when thick enough ( 100 ms).

The transparent nature of the uppermost seismic unit is indicative of a relatively homogeneous interval that contains no significant impedance contrasts. This interval correlates to pelagic brown clay (14 $\mathrm{m}$ at Site $802,61 \mathrm{~m}$ at Site $801,38 \mathrm{~m}$ at Site $800,72 \mathrm{~m}$ at Site 61 , and $25 \mathrm{~m}$ at Site 452). At Site 800 the Miocene pelagic clay lies unconformably over Upper Cretaceous chert but at Site 801 there is inadequate biostratigraphic data to identify any possible hiatus between the Tertiary pelagic clay and underlying Upper Cretaceous chert. The topmost $30 \mathrm{~ms}$ at Site 802 correspond to the upper Pliocene to Quaternary pelagic brown clay representing slow pelagic deposition and authigenesis below the CCD (Lancelot, Larson, et al., 1990).

\section{DISCUSSION}

\section{Basinwide Distribution of Sediments Recovered During Leg 129}

Sediment accumulation and distribution are largely controlled by the variation in the seafloor depth through time, temporal changes in the sources for redeposited sediments, and time-varying fluctuations in the CCD. The huge output of mid-plate volcanism primarily during the mid-Cretaceous directly affected the first two of these controls and most likely altered the CCD in a nonlinear way by at least doubling the atmospheric $\mathrm{pCO}_{2}$ (Arthur et al., 1985, 1991). Thus the mid-Cretaceous volcanic event dominates the sedimentary history of these basins from the latest Barremian-Aptian onward through the Late Cretaceous. Redeposited sediments make up virtually the entire drilled interval at Site 585 and Site 802 in the EMB and represent the majority of the sediment penetrated at Sites 800 and 

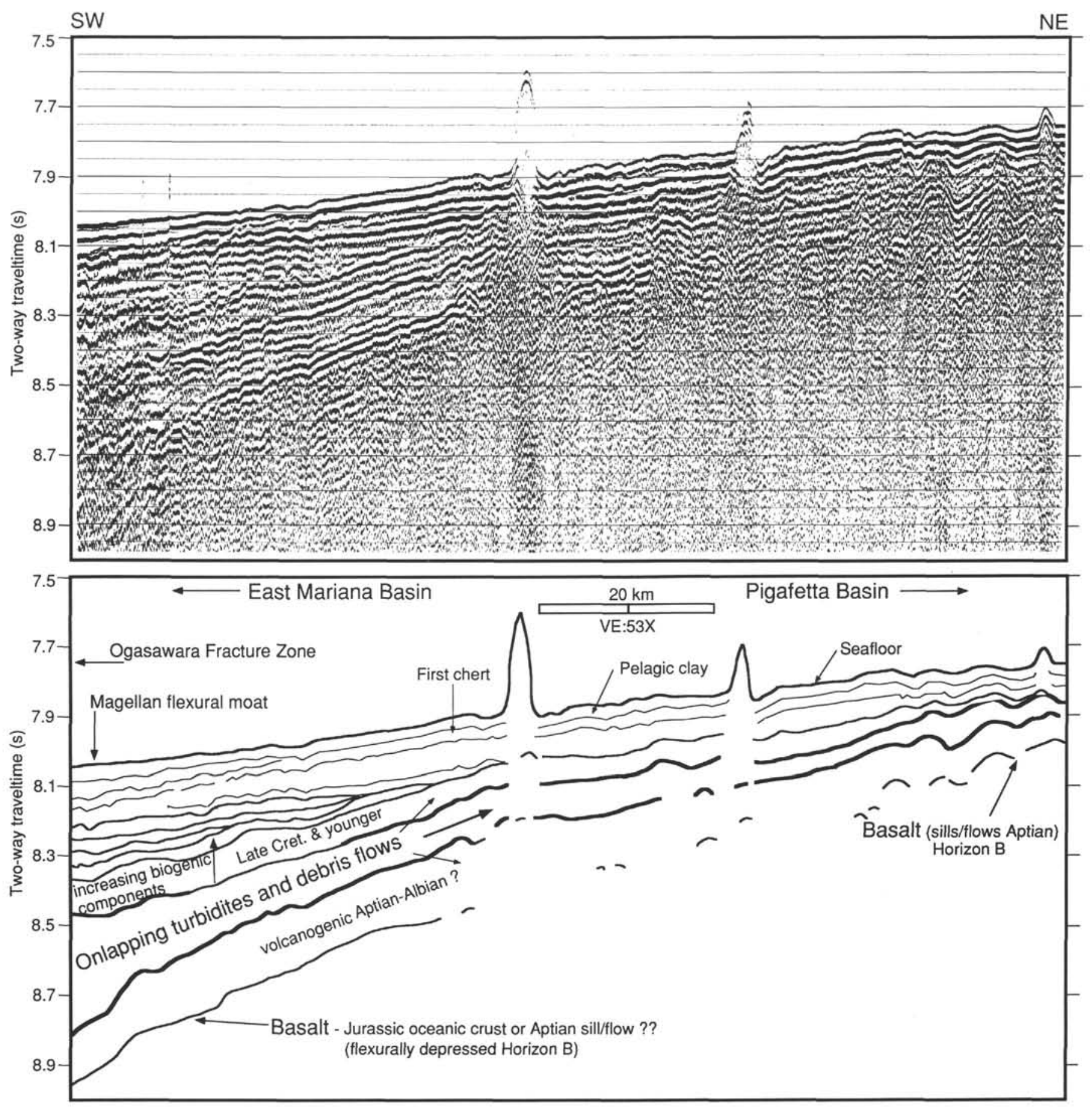

Figure 10. MESOPAC II SCS watergun profile from the PB (right side) to the EMB crossing approximately perpendicular to the inferred trend of the Ogasawara Fracture Zone. The seismic image is strikingly similar to those across the Hawaiian flexural moat (Rees et al., in press). Reflections clearly show onlapping geometries interpreted as moat-filling debris flows and turbidites derived from the Magellan Seamounts. These seamounts are aligned along the trend of the Ogasawara Fracture Zone and appear to flexurally depress high-velocity Horizon B over a 120-km range (e.g., flexural wavelength) on the PB side of the fracture zone. This near-channel record is processed and displayed with the following parameters: mute, 2-trace mix, band-pass filter $25-100 \mathrm{~Hz}$, water-velocity F/K migration, $500-\mathrm{ms} \mathrm{AGC}$, and VE of $\sim 53 \times$ at $1.5 \mathrm{~km} / \mathrm{s}$. 
801 in the PB. The age and stratigraphic relationships derived from the correlation of drilling results with seismic stratigraphy allow us to map the vertical, as well as the lateral extent of these deposits on a basinwide scale.

\section{Tertiary Turbidites of the EMB}

Results from DSDP Sites 199 and 585 led investigators to suspect that the upper opaque unit throughout the central EMB represents turbidites dominated by pelagic components rather than abundant autochthonous chert/clay or chert/chalk as is the case in extended portions of the northwest Pacific. Investigators speculated, largely on the basis of the material's shallow-water fossil content and age, that it was derived from the Caroline Islands (Heezen, MacGregor, et al., 1973; Heezen et al., 1973) or from erosion of thick Upper Cretaceous to Eocene pelagic caps atop the surrounding Magellan Seamounts (Moberly, Schlanger, et al., 1986). Seismic profiles across the central EMB, including those from our investigation, revealed stratigraphic relationships consistent with turbidite deposition (Shipley et al., 1983) and indicate that some reflections within the uppermost 250-300 m penetrated at DSDP Sites 199 and 585 (Fig. 6, 8.0-8.4 s TWT) extend across the entire basin (Whitman et al., 1986; this study). Although shallow turbidites were expected in the EMB, the recovery of redeposited, coal-black tuff with minimal calcareous components and the subsequent thickness $(\sim 220 \mathrm{~m})$ of turbidites dominated by tuff was one of Leg 129's surprises.

Results from Site 802 indicate that the youngest volcanic event affecting the sedimentary history of the EMB was the formation of the Caroline Ridge and associated islands, guyots, and reefs (Shipboard Scientific Party, 1990c). Basalts collected from the Caroline Islands (Federated States of Micronesia) show a mean age progression from Kosrae $(1.4 \pm 0.2 \mathrm{Ma})$ to Truk $(10.9 \pm 5.0 \mathrm{Ma}$; i.e., Miocene) (Keating et al., 1984). They display a linear trend that is co-polar with the Hawaiian chain from 0 to $14 \mathrm{Ma}$ and have been inferred to mark the track of the Pacific Plate across a hotspot now located east-southeast of Kosrae (Jarrard and Clague, 1977; Keating et al., 1984). It is difficult to separate the bathymetric expressions of the Caroline Ridge and the Ontong-Java Plateau located just south of the Caroline Islands and it is likely that the Caroline Islands were simply emplaced at the edge of this already anomalously shallow mid-Cretaceous oceanic plateau.

Our seismic stratigraphic observations are consistent with a Caroline Island source location for the tuff recovered at Site 802 and a Magellan seamount source for the Upper Cretaceous-Holocene carbonate turbidites at Sites 199 and 585. The key seismic observations are illustrated in Figures 9 and 5B and show the high-amplitude, semicontinuous reflections correlated to the Miocene tuff/pelagic clay/calcareous material at Site 802 (Fig. 4C) appear to thicken toward the Caroline Ridge and downlap toward the basin reaching a nearly constant thickness of $\sim 150-200 \mathrm{~m}$. The well-indurated tuff penetrated at Site 802, however, does not extend to the margins of the EMB as it is not present at DSDP Sites 59,61, 199, 585, or 452. Our seismic observations indicate the Miocene tuff is derived from sources to the south (Caroline Islands) and appears to extend towards the Ogasawara Fracture Zone and Magellan Seamounts approximately $\sim 250 \mathrm{~km}$ east of Site 802 along one of our seismic profiles. The inferred eastward extent of Miocene tuff in the EMB corresponds to a regional bathymetric high, a subtle shallowing of Horizon B, the thinnest $(\sim 200 \mathrm{~m})$ sedimentary section, and a change from highly reflective (opaque) to a more transparent seismic facies (Fig. 5B). To the east, the Tertiary calcareous turbidites recovered along the eastern margin of the EMB at DSDP Sites 199 and 585 appear to dominate over the tuffaceous component. These turbidites onlap the seamounts to the east (Fig. 6), north and south of DSDP Site 585 (i.e., Ita Mai Tai) (Shipley et al., 1983; Moberly, Schlanger, et al., 1986; this study).

In short, the relatively thick (100-300 m) Tertiary section in the EMB changes from volcanogenic turbidites in the south central to dominantly calcareous turbidites along the eastern margin. To the west and north the Tertiary section becomes pelagic, thins, and is dominated by radiolarian clay. Our seismic profiles, however, do not constrain the location of this transition. A thin Tertiary section that is represented entirely by pelagic clay with varying amounts of volcanic-arc ash is common throughout the western Pacific east of the trench system. In this region DSDP reports all identify hiatuses of varying duration after the Late Cretaceous, most commonly Upper Cretaceous cherts overlain unconformably by a thin layer of Miocene or younger pelagic clays. The central EMB is actually quite unusual in this respect because of the relatively large accumulation of Tertiary turbidites. In addition, the inferred distances traversed $(\sim 300-400$ $\mathrm{km}$ ), the thickness of massive beds (on a meter scale), the unusual mineralogy, and the almost "welded" nature of portions of the Miocene volcaniclastic gravity flows are remarkable (Lancelot, Larson, et al., 1990; Karpoff et al.; Lees et al.; Salimullah, all this volume).

Lees et al. (this volume) report the highly vesicular glass and clasts of alkaline-basaltic nature suggests of late-stage construction of an oceanic island and that shallow-water phreatomagmatic processes could have created hyaloclastic material recovered at Site 802 . There is abundant evidence that hyaloclastic material, such as the tuff recovered in the EMB, can be produced above and below the sea surface by volcanism in a variety of tectonic environments (e.g., not only explosive island arcs) and can be transported great distances. The growth of submarine volcanoes from abyssal depths through the critical depth (pressure) for the onset of explosive volcanism and/or hydromagmatic processes leads to the production of hyaloclastic material. For example, Batiza et al. (1984) provide convincing evidence for lava fountaining even at depths $>3000 \mathrm{~m}$ which created abundant hyaloclastite deposits on young seamounts near the East Pacific Rise and ash-size glass shards are presently being produced at active submarine volcanoes such as "Kick em Jenny" (Sigurdsson et al., 1980). Hyaloclastite grain-flow deposits recovered during DSDP Leg 47, interpreted to have formed subaqueously during the initial growth of one of the Canary Islands, have been redeposited at least $100 \mathrm{~km}$ into the surrounding basin (Schmincke and von Rad, 1979). Subaerial pyroclastic flows entering the sea from eruptions in the Lesser Antilles initiated subaqueous pyroclastic debris flows (including charred wood) which were deposited (up to $5 \mathrm{~m}$ thick) in the Grenada Basin more than $250 \mathrm{~km}$ from the known island source (Carey and Sigurdsson, 1980).

The steep slopes $\left(4^{\circ}-9^{\circ}\right.$ over $\left.\sim 50 \mathrm{~km}\right)$ of the Caroline islands/seamounts/atolls allows for the acceleration and long transport distances across the more regional gentle gradient $\left(0.2^{\circ}\right)$ from the Caroline Ridge ( $5000 \mathrm{mbsl})$ to the EMB at $5800-6100 \mathrm{mbsl}$. Small amounts of upper Miocene-Pliocene volcanic ash noted at DSDP Site 462 in the Nauru Basin (Fig. 1) were interpreted to relate to the formation of the easternmost Caroline Island of Kosrae (Larson, Schlanger, et al., 1981). The lack of thick tuff deposit at Site 462 in the Nauru Basin $\sim 300 \mathrm{~km}$ east of the youngest Caroline Island, Kosrae, and the greater number and size of seamounts/atolls bordering the EMB to the south, indicate that volcanic activity of the Caroline Hotspot was much more robust in the Miocene than at present. The large east-west component of plate motion $(\sim 100$ $\mathrm{km} / \mathrm{m} . \mathrm{y}$.) indicates that DSDP Site 462 was more than $1000 \mathrm{~km}$ east-southeast of the hotspot during the Miocene while Site 802 would have remained within $300-400 \mathrm{~km}$ north of the more intense Miocene volcanic activity which was presumably creating Truk and surrounding atolls.

\section{Cretaceous Turbidites in the East Mariana Basin}

Reflections of the lower transparent unit in the EMB terminate against or onlap the Aptian basalt surface as it rises out of the EMB toward the Caroline Ridge (Figs. 5B and 9), indicating that the Coniacian-upper Campanian turbidites penetrated at Site 802 do not originate from sources to the south (e.g, the flanks of the Ontong-Java 
Plateau). The Aptian flow/sill surface and overlying Upprt Cretaceous turbidites appear to onlap or thin onto Ita Mai Tai Ridge, and basalt dredged from Ita Mai Tai Guyot (Figs. 2 and 7) has been radiometrically dated at $120 \pm 1.0 \mathrm{Ma}$ (M. Pringle, pers. comm., 1991). In addition, the Upper Cretaceous volcanic turbidites (Unit V, Site 802) do not have a correlative volcanic deposit at DSDP Site 585 where older, Aptian-Albian volcanic debris were recovered (Figs. 4C and 6) (Moberly, Schlanger, et al., 1986; Shipboard Scientific Party, 1990c). These relationships indicate that the source(s) for the Upper Cretaceous volcanic deposits recovered in the central EMB must be to the west of Site 802 or from a seamount(s) in the Magellan Group younger than those immediately surrounding DSDPSite 585 (e.g., Ita Mai Tai). DSDP Site 61 lies $\sim 625 \mathrm{~km}$ west of Site 802 proximal to a seamount province just seaward of the Mariana Trench. Here, Santonian-age radiolarian clay lies in depositional contact/ interbedded with basalt flows. These flows lie $\sim .03 \mathrm{~s}$ above a regional basement reflection (Shipboard Scientific Party, 1971) and are interpreted to relate to the growth of surrounding seamounts, implying that these seamounts may have acted as a source for Upper Cretaceous volcanic material. The northwest-southeast linear trend of the Magellan Seamounts is, we think, structurally controlled by the Ogasawara Fracture Zone and does not represent a systematic time progressive trace of a hotspot (see following sections). While Ita Mai Tai Guyot is Aptian in age, basalt dredged from the seamount labeled " $86 \mathrm{Ma}$ " in Figure 7 has been radiometrically dated $\left({ }^{40 / 39} \mathrm{Ar}\right)$ at $86 \pm 1.0 \mathrm{Ma}$ (M. Pringle, pers. comm., 1991), indicating that this Magellan seamount was created, or was at least volcanically active, during the Santonian. It seems possible, then, that the seamount(s) of the Magellan group and those bordering the EMB to the west provided the central EMB with episodic, distal volcanic/biogenic turbidites of Late Cretaceous age. However, if some of the Magellan group are the source for volcanic/biogenic debris younger than Albian, why are there virtually no volcanic turbidites of this age recovered at Site 801 in the PB? One explanation lies in the structural control of sediment distribution imposed by the Ogasawara Fracture Zone and Magellan Seamounts which separate the PB and EMB.

\section{Ogasawara Fracture Zone and Flexural Moat}

Magnetic anomalies M22-M36 are offset approximately $500 \mathrm{~km}$ left-laterally from the EMB to the PB and are separated by a region approximately $300 \mathrm{~km}$ wide. The fracture zone(s) that offset these lineations is an original feature of the Jurassic Pacific Plate and is inferred to lie somewhere within this broad zone; however, its primary morphotectonic expression is not clearly defined bathymetrically. Seamounts of the Magellan group are scattered within this region and appear to be aligned approximately perpendicular to magnetic lineations and thus lie along the trend inferred for a fracture zone offset. Intraplate volcanism in the form of volcanoes and elongate ridges that are localized along and within fracture zones is well documented and has been used as an argument for a weakened lithosphere along fracture zones (Vogt, 1974; Batiza, 1981; Lowrie et al., 1986). The apparent alignment of the southern Magellan Seamounts along this fracture zone, in addition to age constraints from dredge samples and cored redeposited volcanogenic material indicate that it may have become one of many focal points for mid-plate volcanism beginning in the Aptian and extending into the Santonian.

Sediment-unloaded Horizon B (following Crough, 1983; Renkin and Sclater, 1988), derived from our MCS profiles, plunges approximately $600 \mathrm{~m}$ over $32 \mathrm{~km}$ as this inferred fracture zone is approached along an FM35-12 track from the EMB across DSDP Site 585 toward the PB (see Fig. 3 for location; Fig. 6). The deepening of Horizon B over distances of $20-40 \mathrm{~km}(\sim 19 \mathrm{~m} / \mathrm{km})$ is comparable to that observed for oceanic crust proximal to large offset fracture zones in the North Pacific (e.g., Mendocino) as well as along the present-day East Pacific Rise axis as transform discontinuities are approached. Correlations of seismic stratigraphy with drilling results from DSDP Site
585 indicate that the total depth reached at this site corresponds to a zone of relatively high-amplitude conformable reflections at approximately 8.9 to 9.0 s TWT (Moberly, Schlanger, et al., 1986; this study) and may correlate with the well-cemented, Aptian-age volcaniclastic turbidites and debris flows lying $260 \mathrm{~m}$ above the high-velocity basement at $1150 \mathrm{mbsf}$ ( $9.2 \mathrm{~s}$ TWT) as determined by sonobuoy 20 (Abrams et al., in press) (Figs. 5C and 6). The anomalous depth to volcanic basement at Site 585 of $\sim 7250 \mathrm{mbsl}$, compared to the depth of Horizon B (6100-6500 mbsl) in the majority of the EMB and PB, marks this area as the trough of the Ogasawara Fracture Zone. The simplified interpretation of stratigraphy in this region (Fig. 6) indicates that reflections correlated with Aptian-Albian debris flow/turbidites do not extend beyond the immediate vicinity of DSDP Site 585 and that only reflectors correlated to latest Cretaceous and younger calcareous turbidites extend into the EMB. It appears that the preexisting fracture zone trough trapped the majority of the large-scale, initial mass-wasting deposits of Aptian-Albian age close to the volcanic source.

Farther to the north along the MESOPAC II seismic profile from the PB toward the EMB, Horizon B appears to deepen over a much broader zone, approximately $640 \mathrm{~m}$ over $120 \mathrm{~km}$ (Figs. 5B and 10). This profile has a decidedly flexural shape that can be modeled by a broken elastic plate with an effective elastic thickness $\left(T_{e}\right)$ of $28.5 \mathrm{~km}$ which is loaded at a free end (Abrams, 1992). The axis of the Ogasawara Fracture Zone lies to the west of this profile (see Fig. 3 for location; Figs. 5B and 10). Our single seismic profile of this area (Fig. 10) is strikingly similar to MCS and SCS profiles across the Hawaiian flexural moat (ten Brink and Watts, 1985; Rees et al., in press) which reveal a thick wedge of well-stratified material with reflectors dipping and diverging toward the island/seamount source and onlapping the rising volcanic basement reflection (e.g., Horizon B). The reflection geometry of the Hawaiian moat has been interpreted as a series of stacked debris flows that thicken toward the source and overlie pre-moat pelagic sediments of constant thickness (Rees et al., in press).

Similarly, we have interpreted the relatively transparent intervals bounded by highly reflective continuous horizons displayed in Figure 10 as a sequence of episodic debris flows bounded by well-bedded turbidites. The lowermost interval overlying Horizon B appears to maintain a fairly uniform thickness with slight thinning toward the PB (e.g., away from the seamount load). This interval was deposited when Horizon B was nearly flat or soon after emplacement of the load; thus this sequence could represent Jurassic-age pelagic sediments or poorly bedded Aptian-Albian debris from the seamount load (as at Site 585). The overlying reflections that make up the majority of the section are unquestionably onlapping/thinning toward the PB and represent redeposited volcanic/carbonate material filling in the flexural moat and spilling out onto the PB. The uppermost units which we interpret as Upper Cretaceous (i.e., younger than Albian) turbidites-debris flows clearly pinch out over $\sim 100 \mathrm{~km}$, while it appears that the lowermost units continue to overlie Horizon B into the PB over ranges greater than $100 \mathrm{~km}$. Our preferred interpretation of Horizon B in this area of the PB is that it represents sills/flows no older than Aptian ( $<124 \mathrm{Ma}$ ) (Abrams et al., in press) and that the immediately overlying units are Aptian-Albian volcanogenic debris flows/turbidites. Overlying turbidite units represent an ever-decreasing sediment supply, and an increasing calcareous component with possible input from renewed volcanism of approximately Santonian age. These Upper Cretaceous turbidites are effectively trapped within what appears to be a flexural moat. Thus on the PB side of the Ogasawara Fracture Zone/flexural moat, Aptian-Albian turbidites extend into the PB while younger calcareous/volcanic turbidites do not. In the EMB just the opposite occurs, as Aptian/Albian turbidites are largely confined by the deep trough of the fracture zone. These conclusions are based only on the limited (just two profiles) seismic observations but are consistent with the drilling results in the PB (i.e., Site 801 ) and EMB. It is likely that volcanogenic turbidites of 
Aptian-Albian age extend into the EMB at other localities, perhaps along the northern margin. For example, drilling results of DSDP Site 452 document Upper Cretaceous chert at $\sim 25$ mbsf and reprocessed (1976 vintage) MCS and sonobuoy data indicates that volcanic basement (i.e., Horizon B) lies at $~ 500$ mbsf and is overlain by a seismic section most similar to Site 800 (Abrams, 1992). To a greater extent than the similarities in seismic facies, the $\sim 500 \mathrm{~m}$ thickness between Campanian-age chert and basement implies significant redeposition of presumably Aptian and younger age.

\section{Correlations between Sites 800 and 801 in the Pigafetta Basin}

It is possible to confidently trace reflectors corresponding only to Horizon B, to the top of Upper Cretaceous chert/porcellanite/clay, and to seafloor over the $\sim 550-\mathrm{km}$ distance separating Sites 800 and 801 (Fig. 5A). There is, however, another, more localized and distinctive reflection horizon labeled "pre-Aptian unconformity" (Figs. 4B and $5 \mathrm{~A})$ that marks the sudden change from clayey radiolarites below $\sim 318$ mbsf to volcaniclastic turbidites above at Site 801 (Shipboard Scientific Party, 1990b; Ogg et al., this volume). The interval between Horizon B and the "pre-Aptian unconformity" essentially represents the Upper Jurassic-Lower Cretaceous pelagic sediment present in the PB. Unfortunately, it has proven difficult to confidently identify this reflection between Sites 801 and 800 . To the southwest of Site 801, this reflection is discontinuous and appears to truncate against or merge with Horizon B at the "rough-smooth boundary," implying that southeast of this boundary all pre-Aptian material lies buried beneath sills/flows no older than Aptian (Figs. 5A and 7). The reflection corresponding to the Early Cretaceous unconformity also appears intermittently along a watergun profile for $\sim 200 \mathrm{~km}$ northwest of Site 801 (Fig. 5A). Beyond this point this reflection can no longer be uniquely identified by its position between two relatively transparent seismic units. Thus, we are only able to map thickness variations of Upper Jurassic-Lower Cretaceous pelagic sediments between Site 800 ( $\sim 50 \mathrm{~m}$ thick) and Site 801 ( $140 \mathrm{~m}$ thick) over a portion of the $\sim 550 \mathrm{~km}$ distance between these sites. We cannot, however, identify any seismic stratigraphic relationships that suggest that this pelagic interval (or portion of) is missing or buried between Sites 800 and 801 other than in the restricted areas where Horizon B has been interpreted as Aptian sills/flows rather than the top of Jurassic oceanic crust (Fig. 7) (Abrams et al., in press).

Site 801 is located on the distal south-southwest flank of a broad regional high protruding into the PB which defines the Marcus-Wake Seamount region (Figs. 2, 5A, 7). Winterer et al. (in press) report radiometric dates ranging from 82 to $102 \mathrm{Ma}$ (i.e., Campanian-Albian) from four seamounts of the Marcus-Wake Group to the northeast of Site 801 (Figs. 2 and 7); these dates bound the age range of volcaniclastic turbidites at Site 801. Data analyses presented in Lees et al. (this volume) indicate a shallow-water off-ridge seamount source for all volcaniclastic turbidites recovered during Leg 129 and the above relationships favor a seamount source location east-northeast of Site 801. Such broad regional uplift east-northeast of Site 801 may also contribute to the apparent dip of pre-Aptian strata to the west-southwest reported by Ogg et al. (this volume). In contrast, Site 800 is surrounded by much larger and more proximal individual seamounts (Figs. 2 and 7) specifically Himu (120 Ma; $~ 80 \mathrm{~km})$ and Golden Dragon $(95 \mathrm{Ma} ; 110 \mathrm{~km})$. The sills penetrated at Site 800 show distinct isotopic affinities to dredged basalts of both Himu and Golden Dragon seamounts (i.e., high radiogenic lead, Castillo et al., this volume; Smith et al., 1989). This result coupled with the proximity to Site 800 make Himu and Golden Dragon seamounts the most likely sources for both deep-sea sills and volcaniclastic debris flows/turbidites recovered at Site 800 (Lancelot, Larson, et al., 1990; Castillo et al.; Lees et al., both this volume).

\section{Plate Motion and Seismic Stratigraphy}

The earliest DSDP forays into the northwest Pacific found that the upper opaque seismic facies corresponded to massive chert accumulation underlying a relatively thin layer of pelagic clay. The diachronous nature of this shallow "first" chert was recognized by these early investigations (Fisher, Heezen, et al., 1971; Heezen, MacGregor, et al., 1973). Heezen et al. (1973) argued that the time-transgressive nature of the shallowest (youngest) chert probably marked the passage of different sites at varying times beneath the equatorial zone of high biogenic productivity. Subsequent investigations revealed that the youngest chert is not typically associated with equatorial carbonate in the older, deeper portions of the Pacific and that the correlation of "first" chert with the upper opaque unit can be used to infer plate motion from seismic stratigraphy (Lancelot and Larson, 1975).

Aspects of the geophysical and sedimentary record which reflect the paleolatitude of sites in the PB and EMB are discussed in detail by Larson et al.; Larson and Sager; Karpoff; Ogg et al.; Erba; and Steiner and Wallick (all this volume). It seems clear from these studies that the periods of largest biosiliceous sedimentation correlate to sub-equatorial paleolatitudes during the Cenomanian-Campanian at both Sites 800 and 801 in the PB and somewhat latter in the EMB ( Campanian-Eocene). The subsequent diagenesis of primary biogenic silica (Behl and Smith, this volume) creates chert/porcellanite. The large impedance contrast between a thin layer $(0-100 \mathrm{~m})$ of pelagic clay and the shallow chert/porcellanite/clay creates the distinctive high-amplitude semicontinuous series of reflections which are easily followed throughout the PB and northern EMB (Fig. 5). Following DSDP Leg 20 it was believed that the upper opaque unit in the EMB did not represent the top of chert/porcellanite/clay $\pm s$ chalk sequence but was instead a thick sequence of carbonate turbidites (i.e., DSDP Site 199, Heezen, MacGregor, et al., 1973). Basinwide seismic profiles have shown that the reflection geometry is indeed consistent with a basin-filling turbidite sequence, which was further confirmed at Site 802 , where the story is complicated by volcanogenic turbidites from the Caroline Hotspot (Shipley et al., 1983; this study). Thus, the identification of a seismic unit representing a paleoequatorial crossing may be obscured in the EMB. Whitman et al. (1986) first noted that the increase in chert/chalk silicified limestone of mid-Eocene-upper Campanian defining unit II at DSDP Site 585 was correlated to a distinct high-amplitude reflection ( 8.4 s TWT) which continued out into the EMB. Our seismic profiles reveal that this horizon appears as a series of semicontinuous reflections (waterguns) and/or a single, higher amplitude event (airguns) that can be traced between DSDP Site 585-Site 802 and throughout the EMB. At Site 802 upper Paleocene-lower Eocene quartz chert is first recovered below 292 mbsf within redeposited nannofossil chalk (Shipboard Scientific Party, 1990c; Behl and Smith, this volume) and is correlated to the reflections at 8.2-8.3 s TWT (Fig. $4 \mathrm{C}$ ) which in turn can be traced to reflections at $\sim 8.4 \mathrm{~s}$ TWT at DSDP Site 585 (Fig. 6) and $\sim 8.3 \mathrm{~s}$ TWT at DSDP Site 199. Increased chert abundance, representing an equatorial crossing, is consistent with paleolatitudes derived for Site 802 (Larson et al., this volume). However, it is also clear that in sediments younger than Eocene, diagenetic chert is rarely found even with an abundant biosiliceous source (Lancelot and Larson, 1975; Behl and Smith, this volume), and so it appears that this reflection(s) may also define pre- to post-Eocene material in the EMB.

The basinwide continuity of the first chert reflection indicates that redeposition events had become less frequent by this time, and is quite useful for defining basinwide trends in sedimentation. The highest amplitude reflections of the chert/chalk/clay (Units III and IV) and weaker events below appear to truncate against, or onlap Horizon B rising toward the Caroline Ridge indicating that Eocene or younger sediments dominate the sedimentary section overlying volcanic base- 
ment on the Caroline Ridge (Figs. 5B and 9). To the east the first chert horizon rises in section and the overlying material changes from chalk-tuff to nannofossil ooze/chalk/pelagic clay and the thickness of underlying calcareous turbidites increases (Figs. 5B and 5C). Immediately east of the Ogasawara Fracture Zone the first chert appears quite shallow, indicating a much-reduced Tertiary section that is observed throughout the majority of the PB. Only the latest equatorial crossing of the Pacific Plate can be correlated to a distinct basinwide reflection; however, there is evidence that the Pacific Plate may have crossed the equator from north to south, or at least was within $0^{\circ}-10^{\circ} \mathrm{S}$ latitude in the Upper Jurassic (Larson et al.; Larson and Sager; Ogg et al.; Steiner and Wallick; all this volume).

\section{CONCLUSIONS}

1. A thin $(<400 \mathrm{~m})$ semicontinuous sequence of mid-Cretaceous (lower Aptian) deep-sea flows/sills overlie Jurassic oceanic crust and Upper Jurassic-Lower Cretaceous sediments throughout the entire EMB and southeast PB. The high-amplitude, flat-lying Horizon B reflection is created by the impedance contrast between low-velocity sediment $(2 \mathrm{~km} / \mathrm{s})$ and high-velocity $(>5 \mathrm{~km} / \mathrm{s})$ flows/sills. Jurassic oceanic crust and overlying Upper Jurassic-Lower Cretaceous sediments unquestionably exist at Site 801 and extend uncovered by younger massive igneous material semicontinuously between Site 801 and Site 800.

2. The Ogasawara Fracture Zone is a primary tectonic feature of the embryonic Pacific Plate. This fracture zone acted as a focal point for Aptian-age extrusive activity as indicated by the coincident alignment of seamounts. This seamount load flexurally depressed the lithosphere surrounding the fracture zone. The resulting morphotectonic features (seamounts, fracture zone, flexural moat) separate the $\mathrm{PB}$ from the EMB and influence the source and distribution of redeposited material.

3. Stratigraphic, lithologic, and age relationships indicate that Cretaceous turbidite sequences in both basins were derived from Magellan and Marcus-Wake seamounts and seamount chains of Aptian age or younger. The seamounts and atolls of the Caroline Ridge were the source of extensive Miocene-age volcanogenic turbidites, some of which are both thick and fine-grained, with sources over 300 $\mathrm{km}$ to the south of Site 802 . The carbonate caps developed on Ita Mai Tai Guyot and other edifices of the Magellan chain were the source for the redeposited shallow-water carbonate sequences recovered along the eastern margin of the EMB.

4. A distinct basinwide reflection correlated with the shallowest chert/porcellanite/clay and chert/chalk sequences in the PB and EMB, respectively, is a time-transgressive horizon ( Eocene-Campanian), resulting from the passage of the Pacific Plate beneath the equatorial zone of high productivity.

\section{ACKNOWLEDGMENT}

This work was part of a joint U.S.-French effort to investigate the western Pacific basins. We wish to thank the ships crew and scientific party of the R/V Fred Moore (RIP) cruise FM35-12 and N/O Le Suroit. Perry Crampton and fellow airgun techs worked beyond the call of duty. Steffen Saustrup, Mark Wiederspahn, and Patty Ganey at the Institute for Geophysics, University of Texas, provided invaluable assistance in the processing of FM35-12 navigation and seismic data. Roland Schlich kindly provided the use of facilities at the Institut de Physique du Globe, Strasbourg, France, and Marc Schaming, Jacques Renault, and Cecille Pourcellot facilitated the processing of MESOPAC II seismic data. Discussions with Bob McMaster, Bob Detrick, and Nancy Grindlay; reviews by J. Lincoln and an anonymous reviewer; and editorial comments of L. Dearmont improved this paper. This project was funded by NSF grants OCE 86-13867 (R. Larson), OCE 86-13641 (T. Shipley), and by JOI/USSAC Ocean
Drilling Fellowship (JSG-CY5-4) and a USSAC grant (20431) to the first author.

\section{REFERENCES}

Abrams, L. J., 1992. Seismic stratigraphy, crustal structure, and volcanic and sedimentary history of the East Mariana and Pigafetta basins of the western Pacific [Ph.D. dissert.]. Univ. of Rhode Island, Kingston.

Abrams, L. J., Larson, R. L., Shipley, T. H., and Lancelot, Y., 1988. Cretaceous volcanic sequences and Jurassic(?) crust in the western Pacific. Eos, 69:1442.

, in press. Cretaceous volcanic sequences and Jurassic crust in the East Mariana and Pigafetta Basins of the western Pacific. In Pringle, M., and Sager, W. (Eds.), The Mesozoic Pacific. Am. Geophys. Union, Monogr.

Arthur, M. A., Dean, W. A., and Schlanger, S. O., 1985, Variations in the global carbon cycle during the Cretaceous related to climate, volcanism, and changes in atmospheric $\mathrm{CO}_{2}$, in Sundquist, E. T., and Broecker, W. S. (Eds.), The Carbon Cycle and Atmospheric $\mathrm{CO}_{2}$ : Natural Variations Archean to Present. Am. Geophys. Union Monogr., 32:504-529.

Arthur, M. A., Kump, L. R., Dean, W. E., and Larson, R. L., 1991. Superplume, supergreenhouse? Eos, 72:301.

Batiza, R., 1981. Lithospheric age dependence of off-ridge volcano production in the North Pacific. Geophys. Res. Lett., 8:853-856.

Batiza, R., Fornari, D., Vanko, D., and Londsdale, P., 1984. Craters, calderas and hyaloclastites on young Pacific seamounts. J. Geophys. Res., 89:8731-8390.

Carey, S. N., and Sigurdsson, H., 1980. The Roseau Ash: deep-sea tephra deposits from a major eruption on Dominica, Lesser Antilles Arc. J. Volcanol. Geotherm. Res., 7:67-86.

Crough, S. T., 1983. The correction for sediment loading on the seafloor. J. Geophys. Res., 88:6449-6454.

Edgar, N. T., Saunders, J. B., et al., 1973. Init. Repts. DSDP, 15: Washington (U.S. Govt. Printing Office).

Ewing, J., Ewing, M., Aitken, T., and Ludwig, W. J., 1968. North Pacific sediment layers measured by seismic profiling. In Drake, C. L., and Hart, P. J. (Eds.), The Crust and Upper Mantle of the Pacific Area. Am. Geophys. Union Monogr., 12:147-173.

Ewing, J., Talwani, M., Ewing, M., and Edgar, T., 1967. Sediments of the Caribbean. Int. Conf. Tropical Oceanogr. Proc., 5:88-102.

Fisher, A. G., Heezen, B. C., et al., 1971. Init. Repts. DSDP, 6: Washington (U.S. Govt. Printing Office).

Handschumacher, D. W., and Gettrust J. F., 1985. Mixed polarity model for the Jurassic "Quiet Zones": new oceanic evidence of frequent pre-M25 reversals. Eos, 66:867.

Handschumacher, D. W., Sager, W. W., Hilde, T.W.C., and Bracey, D. R., 1988. Pre-Cretaceous tectonic evolution of the Pacific plate and extension of the geomagnetic polarity reversal time scale with implications for the origin of the Jurassic "Quiet Zones." Tectonophysics, 155:365-380.

Harland, W. B., Armstrong, R. L., Cox, A. V., Craig, L. E., Smith, A. G., Smith, D. G., 1990. A Geologic Time Scale 1989: Cambridge (Cambridge Univ. Press).

Heezen, B. C., MacGregor, I. D., Foreman, H. P., Forristal, G., Hekel, H., Hesse, R., Hoskins, R. H., Jones, E.J.W., Kaneps, A., Krasheninnikov, V. A., Okada, H., and Reuf, M. H., 1973. Diachronous deposits: a kinematic interpretation of the post Jurassic sedimentary sequence on the Pacific plate. Nature, 241:25-32.

Hilde, T.W.C., Isezaki, N., and Wageman, J. M., 1976. Mesozoic seafloor spreading in the North Pacific. In Sutton, G. H., Manghnani, M. H., and Moberly, R. (Eds.), The Geophysics of the Pacific Ocean Basin and its Margins. Am. Geophys. Union, Geophys. Monogr., 19:205-226.

Houtz, R. E., and Ludwig, W. J., 1977. Structure of Columbia Basin, Caribbean Sea, from profiler-sonobuoy measurements. J. Geophys. Res., 82:4861-4868.

Jarrard, R. D., and Clague, D. A., 1977. Implications of Pacific island and seamount ages for the origin of volcanic chains. Rev. Geophys. Space Phys., 15:57-76.

Keating, B. H., Mattey, D. P., Naughton, J., and Helsley, C. E., 1984. Age and origin of Truk Atoll, eastern Caroline Islands: geochemical, radiometricage, and paleomagnetic evidence. Geol. Soc. Am. Bull., 95:350-356.

Kent, D. V., and Gradstein, F. M., 1985. A Cretaceous and Jurassic geochronology. Geol. Soc. Am. Bull., 96:1419-1427.

Lancelot, Y., and Larson, R. L., 1975. Sedimentary and tectonic evolution of the Northwestern Pacific. In Larson, R. L., Moberly, R., et al., Init. Repts. DSDP, 32: Washington (U.S. Govt. Printing Office), 925-939.

Lancelot, Y., Larson, R. L., et al., 1990. Proc. ODP, Init. Repts., 129: College Station, TX (Ocean Drilling Program). 
Larson, R. L., 1976. Late Jurassic and Early Cretaceous evolution of the western central Pacific Ocean. J. Geomagn. Geoelectr., 28:219-236.

Larson, R. L., and Chase, C. G., 1972. Late Mesozoic evolution of the western Pacific Ocean. Geol. Soc. Am. Bull., 83:3627-3644.

Larson, R. L., and Lowrie, W., 1975. Paleomagnetic evidence for motion of the Pacific plate from Leg 32 basalts and magnetic anomalies. In Larson, R. L., Moberly, R., et al., Init. Repts. DSDP, 32: Washington (U.S. Govt. Printing Office), 571-577.

Larson, R. L., Moberly R., et al., 1975. Init. Repts. DSDP, 32: Washington (U.S. Govt. Printing Office).

Larson, R. L., Schlanger, S. O., et al., 1981. Init. Repts. DSDP, 61: Washington (U.S. Govt. Printing Office).

Lowrie, A., Smoot, C. N., and Batiza, R., 1986. Are oceanic fracture zones strong or weak? New evidence for volcanic activity and weakness. Geology, 14:242-245.

Macdonald, K. C., 1982. Mid-ocean ridges: fine scale tectonic, volcanic and hydrothermal processes within the plate boundary zone. Annu. Rev. Earth Planet. Sci., 10:155-190.

Mammerickx, J., and Sharman, G. F., 1988. Tectonic evolution of the North Pacific during the Cretaceous quiet period. J. Geophys. Res., 93:3009-3040.

Moberly, R., Schlanger, S. O., et al., 1986. Init. Repts. DSDP, 89: Washington (U.S. Govt. Printing Office).

Nakanishi, M., Tamaki, K., and Kobayashi, K., 1989. Mesozoic magnetic anomaly lineations and seafloor spreading history of the northwestern Pacific. J. Geophys. Res., 94:15437-15462.

in press. Magnetic anomaly lineations from Late Jurassic to Early Cretaceous in the west-central Pacific Ocean. Geophys. J. Int.

Ozima, M., Kaneoka, I., Saito, K., Honda, M., Yanagisawa, M., and Takigami, Y., 1983. Summary of geochronological studies of submarine rocks from the western Pacific Ocean. In Hilde, T.W.C., and Uyeda, S. (Eds.), Geodynamics of the Western Pacific-Indonesian Region, 11:137-142.

Pringle, M., 1992. Geochronology and petrology of the Musicians Seamounts and the search for hot spot volcanism in the Cretaceous Pacific [Ph.D. dissert.]. University of Hawaii, Honolulu.

Rees, B. A., Detrick, R. S., and Coakley, B. C., in press. Seismic stratigraphy of the Hawaiian flexural moat. Bull. Geol. Soc. Am.

Renkin, M., and Sclater, J. G., 1988. Depth and Age in the North Pacific. J. Geophys. Res., 93:2919-2935.

Sager, W. W., Handschumacher, D. W., Hilde, T.W.C., and Bracey, D. R., 1988. Tectonic evolution of the northern Pacific plate and Pacific-FarallonIzanagi triple junction in the Late Jurassic and Early Cretaceous (M21M10). Tectonophysics, 155:345-364.

Sager, W.W., and Pringle, M. S., 1988. Mid-Cretaceous to Early Tertiary apparent polar wander path of the Pacific plate. J. Geophys. Res., 93:11753-11771.

Saunders, J. B., Edgar, N. T., Donnelly, T. W., and Hay, W. W., 1973. Cruise synthesis. In Edgar, N. T., Saunders, J. B., et al., Init. Repts, DSDP, 15: Washington, D.C. (U.S. Govt. Printing Office), 1077-1111.

Schlanger, S. O., Jenkyns, H. C., and Premoli Silva, I., 1981. Volcanism and vertical tectonics in the Pacific basin related to global Cretaceous transgressions. Earth Planet. Sci. Lett., 52:435-449.
Schmincke, H.-U., and von Rad, U., 1979. Neogene evolution of Canary Island volcanism inferred from layers and volcaniclastic sandstones of DSDP Site 397. Init. Repts. DSDP, 47 (Pt. 2), Washington (U.S. Govt. Printing Office), 703-716.

Shipboard Scientific Party, 1971. Site 61. In Winterer, E. L., Reidel, W. R., et al., Init. Repts. DSDP, 7 (Pt. 1): Washington (U.S. Govt. Printing Office), $27-48$. 1973. Mesozoic chalks beneath the Caroline abyssal plain: DSDP Site 199. In Heezen, B. C., MacGregor, I. D., et al., Init. Repts. DSDP, 20: Washington (U.S. Govt. Printing Office), 65-85.

, 1990a. Site 800. In Lancelot, Y., Larson, R. L., et al., Proc. ODP, Init. Repts., 129: College Station, TX (Ocean Drilling Program), 33-89. , 1990b. Site 801. In Lancelot, Y., Larson, R. L., et al., Proc. ODP. Init. Repts., 129: College Station, TX (Ocean Drilling Program), 91-170. , 1990c. Site 802. In Lancelot, Y., Larson, R. L., et al., Proc, ODP Init. Repts., 129: College Station, TX (Ocean Drilling Program), 171-243.

Shipley, T. H., Whitman, J. M., Duennebier, F. K., and Peterson, L. D., 1983. Seismic stratigraphy of the East Mariana Basin, western Pacific. Earth Planet. Sci. Lett., 64:257-275.

Sigurdsson. H.. Sparks, R.S.J., Carey, S. N., and Huang, T. C., 1980. Volcanogenic sedimentation in the Lesser Antilles Arc. J. Geol., 88:523-540.

Smith, W.H.F.. Staudigel, H., Watts, A. B., and Pringle, M., 1989. The Magellan Seamounts: Early Cretaceous record of the South Pacific isotopic and thermal anomaly. J. Geophys. Res., 94:10501-10523.

Tamaki, K., and Larson, R. L., 1988. The Mesozoic tectonic history of the Magellan microplate in the Western Central Pacific. J. Geophys. Res., 93:2857-2874.

Tamaki, K., Nakanishi, M., Sayanagi, K., and, Kobayashi, K., 1987. Jurassic magnetic anomaly lineations of the Western Pacific and the origin of the Pacific plate. Eos, 68:1493.

ten Brink, U. S., and Watts, A. B., 1985. Seismic stratigraphy of the flexural moat flanking the Hawaiian Islands. Nature, 312:421-424.

Vogt, P. R., 1974. Volcano spacing, fractures and thickness of the lithosphere. Earth Planet. Sci. Lett., 21:235-252.

Whitman, J. M., Baltuck, M., and Haggerty, J. A., 1986. Turbidite sedimentology and history of the East Mariana Basin. In Moberly, R., Schlanger, S. O., et al., Init. Repts. DSDP, 89: Washington (U.S. Govt. Printing Office), 365-387.

Winterer, E. L., Duncan, R. A., McNutt, M. K., Natland, J. H., Premoli Silva, I., Sager, W. W., Sliter, W. V., Van Waasbergen, R., and Wolfe, C. J., in press. Cretaceous guyots in the northwest Pacific: an overview of their geology and geophysics. In Pringle, M., and Sager, W. (Eds.), The Mesozoic Pacific. AGU Mongr. Ser.

Date of initial receipt: 2 December 1991

Date of acceptance: 30 March 1992

Ms 129B-143 